\title{
1 The Thórólfsfell tuya, South Iceland - a new type of basaltic glaciovolcano
}

2 Alastair G. E. Hodgetts ${ }^{\mathrm{a}, \mathrm{b}, *}$, Dave McGarvie ${ }^{\mathrm{a}}$, Hugh Tuffen ${ }^{\mathrm{a}}$, Isla C. Simmons ${ }^{\mathrm{c}}$

3

$4 \quad{ }^{\text {a }}$ Lancaster Environment Centre, Lancaster University, Lancaster, LA1 4YQ, UK

$5{ }^{\mathrm{b}}$ School of Geography, Earth and Environmental Sciences, University of Birmingham, Edgbaston,

6 Birmingham, B15 2TT, UK

$7 \quad{ }^{\mathrm{c}}$ School of Geosciences, University of Edinburgh, Edinburgh, EH9 3FE, UK

8

$9 \quad *$ Corresponding author email: agh733@bham.ac.uk

*Corresponding author present address:

Alastair G. E. Hodgetts

Aston Webb Block A - Earth Sciences

14 School of Geography, Earth and Environmental Sciences

15 University of Birmingham

16 Edgbaston

17 Birmingham

B15 2TT

ABSTRACT

Basaltic tuyas are glaciovolcanoes that form when substantial focused eruptions take place beneath thick ice. None have been witnessed, so models reconstructing tuya formation are grounded in detailed fieldwork. A key feature of many basaltic tuyas is the presence of volcanic and volcaniclastic rocks that indicate the sustained presence of an encircling meltwater lake during the eruption.

Here we provide the first description of Pórólfsfell (Thórólfsfell), a basaltic tuya from Iceland, which is sufficiently distinct from previously described tuyas to be considered a new type of basaltic glaciovolcano. 
Thórólfsfell is an asymmetric tuya with an area of c. $8 \mathrm{~km}^{2}$, base-to-top height of c. $450 \mathrm{~m}$, and volume of c. $2.2 \pm 0.4 \mathrm{~km}^{3}$ that has been emplaced onto the approximately $12^{\circ}$ sloping lower southern flanks of Tindfjallajökull central volcano.

Thórólfsfell shares only two major morphological characteristics with other basaltic tuyas: (1) a subhorizontal top comprising subaerial lavas; (2) a clear vertical topographic expression, which reflects preferential upwards edifice growth due to lateral confinement by encircling ice and/or meltwater. There is no evidence for the presence of a large and long-lived syn-eruptive meltwater lake. The Thórólfsfell eruption is effusion-dominated, and there is a gradual reduction in cooling fractures in lavas with elevation. The eruption is divided into three Stages. Stage I forms a c.110 m thick drape onto an irregular but persistently c. $12^{\circ}$ dipping basement of older basaltic tuffs; Stage I consists of palaeoslope-parallel lava lobes with abundant cooling fractures, accompanied by abundant breccias. Stage II comprises a c. $240 \mathrm{~m}$ thick stack of c. $12^{\circ}$ dipping stacked lava lobes with abundant cooling fractures, and occasional autobreccias. Stage III is c. $110 \mathrm{~m}$ thick, and whilst early lavas have cooling fractures, the final Stage III lavas are sub-horizontal, subaerial pahoehoe lava flows.

Our model for the formation of Thórólfsfell has two key features. The first is that the inclined basement has facilitated the downslope movement of meltwater away from the eruption site into an efficient gravity-assisted subglacial meltwater drainage system. The second is that there is a close connection between the vertical growth of the tuya and the ice above, with each successive lava in the growing stack being close to and/or in contact with the overlying ice. This repeated process provides the regular (but transient) meltwater supply necessary to produce a c. $350 \mathrm{~m}$ stack of similarly-cooled lava carapaces.

From a hazards perspective, a Thórólfsfell-style eruption is of little concern as rapid and steady meltwater drainage away from the eruption site would prevent the high-magnitude glacial outburst floods that require accumulated meltwater. The Thórólfsfell eruption provides a new perspective on effective meltwater dispersal away from tuya-building eruptions on dipping palaeoslopes, and on 
lava-ice interactions during subglacial eruptions. The products of other subglacial eruptions onto dipping basements, producing Thórólfsfell-type tuyas, await study.

This first description of a new type of basaltic glaciovolcano may aid in the identification and interpretation of similar glaciovolcanoes on Earth and Mars that have yet to be discovered.

Keywords: Glaciovolcanism, Tuya, Basaltic, Effusion-Dominated, Palaeoslope, Lava sheets, Stacked Lava Lobes

\section{INTRODUCTION}

Glaciovolcanic eruptions can produce varied deposits due to many competing physical and thermodynamic processes occurring in the subglacial eruptive environment when magma meets ice and/or meltwater (e.g. Wilson and Head, 2002; Russell et al., 2014; Reynolds et al., 2017). Tuyabuilding eruptions involve focussed, prolonged magma discharge from a point source or short fissure into thick ice, and if the eruption breaches the ice/englacial lake surface it can construct a subaerial lava cap above a subglacially-erupted pedestal (e.g., Matthews, 1947; Smellie and Skilling, 1994; Russell et al., 2007). Ice confinement results in strong vertical growth and their table mountain morphologies. As basaltic magma can melt up to c.14 times its volume of ice (Head and Wilson, 2002; Wilson and Head, 2002) meltwater also plays an important role in basaltic tuya eruptions, via cooling, quenching and fragmenting erupting magma (e.g. Tuffen, 2007), and providing an aqueous environment for the deposition of erupted products (e.g. Smellie, 2006).

\subsection{Glaciovolcanism in Iceland}

Glaciovolcanism is commonplace in Iceland due to a combination of abundant ice and frequent eruptions (e.g., Guðmundsson 2005; Thordarson and Larsen, 2007; McGarvie, 2009; Stevenson et al., 2009; Magnússon et al., 2012; Smellie et al., 2016). Iceland's high latitude means that it has relatively longer glacial periods and shorter interglacial periods than volcanic provinces in lower latitudes, and consequently subglacial volcanoes and their eruptive products are prominent features of the active rift 
zones (the terrestrial equivalent of the mid-ocean ridge system; Pálmason and Saemundsson, 1974). Many well-preserved examples have been exposed by glacial retreat at the end of the last (Weichselian, c. 115 ka - c. 11.7 ka) glacial period (e.g. Skilling, 2009; Räsänen et al., 2015; Turney et al., 2017; Moles et al., 2018). As rhyolite accounts for c.11\% of erupted Icelandic magma, there is now extensive documentation of the products of silicic eruptions into both thick ice sheets and the thinner ice of stratovolcanoes (e.g. Tuffen et al., 2002a; Stevenson et al., 2006; McGarvie, 2009). Rhyolitic subglacial eruptions appear to involve more efficient meltwater drainage than their basaltic equivalents, possibly because cooler and vesicle-rich silicic magma can melt significantly less ice per unit volume than basalt, allowing meltwater more time to escape. This leads to the prevalence of lithofacies associated with well-drained subglacial cavities (e.g. Tuffen et al., 2002b; Tuffen and Castro, 2009), in contrast with basaltic deposits, which typically record the accumulation of significant bodies of meltwater (e.g. Smellie, 2006; Skilling, 2009).

Glaciovolcanism research has expanded rapidly over the past two decades, leading to increasing documentation of glaciovolcanic edifices. Here we adopt the descriptive genetic classification for glaciovolcanoes of Russell et al., (2014), which builds on earlier summaries (e.g. Hickson, 2000; Smellie, 2007; Jakobsson and Guðmundsson, 2008). In this classification, every glaciovolcano is termed a 'tuya', and is divided into four types, based on their geometry. Russell et al., (2014) use two key parameters - the hydrology of the ice vault (i.e. sealed, leaky or well-drained) and eruption style (effusive, transitional, or explosive) to define nine distinct lithofacies associations.

\subsection{A typical Icelandic basaltic tuya}

The most abundant type of documented Icelandic tuya is typified by Hlöðufell (Skilling, 2009), which Russell et al., (2014) classify as a flat-topped basaltic tuya, emplaced in a partly-sealed/leaky ice vault by an effusive-transitional eruption. To provide a helpful contrast with our description of Pórólfsfell (Thórólfsfell), we now briefly summarise this tuya type.

Flat-topped basaltic tuya type IV/Va lithologies, as shown in Fig. 6 of Russell et al., (2014), reflect two trends: (1) a change from initial volatile-rich to later volatile-poor magma; (2) a change from 
higher initial pressures at the ice sheet base to atmospheric pressure during late subaerial activity. There are four resultant constructional stages. In the initial pillow lava stage at the tuya base, high confining pressures prevent volatile-rich basaltic magma from fragmenting extensively via volatile expansion. The tephra production stage involves emplacement of subaqueous-subaerial (Surtseyan) tuffs as the shoaling edifice grows within a water body, reaching the lower confining pressures that permit volatile-driven magmatic explosions. Ephemeral tuff cones are commonly produced, but these are unstable and often collapse, and tephra clasts exhibit subaerial and/or subaqueous clast characteristics.

In the subaerial lava cap and lava-fed delta stage the edifice continues to grow upwards, leading to diminished access of water to the eruption site. Explosive magma-water interactions decline and nonexplosive degassing (i.e. effusion) now dominates, with subaerial lavas, mostly pahoehoe, covering the island of tuff emerging above the meltwater. Lava produced includes inflated, low-angle pahoehoe-dominated lava flow fields typical of subaerial eruptions (e.g. Pedersen et al., 2017), together with prograding, breccia-rich pahoehoe lava-fed deltas where lava lobes encounter meltwater at the edifice edge. The distinct sub-horizontal surface separating subaerial lavas above and dipping breccias below, the 'passage zone', indicates the evolving water level. Although a tuya-building eruption has yet to be observed, pahoehoe lava-fed delta generation has been witnessed - in a marine context in Hawai' $i$ - and products and processes appear strongly analogous to the subglacial setting (e.g. Tribble, 1991; Di Traglia et al., 2018). Intrusion, a further constructional phase, involves emplacement of a plexus of intrusions largely within the tuffs (Skilling, 2009), possibly coinciding with the subaerial lava cap stage. Heat from the intrusions promotes palagonitisation, which binds together vitric shards and inhibits edifice collapse (e.g. Moore and Jackson, 2020; Weaver et al., 2020).

\subsection{Lava sheets and tuff + lava sheets in subglacial settings}

To provide context for the key lithologies observed at Thórólfsfell, we summarise previous work on lava sheets and tuff + lava sheets interpreted to have been emplaced in subglacial settings. Note that we use the term 'tuff + lava sheets' instead of the term 'sheet-like sequences' (e.g. Smellie, 2008). 
The emplacement of lava sheets and tuff + lava sheets in subglacial settings has never been observed, so their existence relies heavily on interpretations of field-based evidence such as: rapid cooling of lava (e.g. chilled margins, high fracture densities); tuffs indicative of rapid cooling and high fragmentation rates; lava morphology (e.g. sub-horizontal, topography-filling, absence of rubbly bases and carapaces); and contact relationships with surrounding rocks (e.g. resting on glacial diamict, intimate association with tuff). See Walker and Blake, 1966; Bergh and Sigvaldason, 1991; Loughlin, 2002; Edwards and Russell, 2002; Smellie, 2008.

Several basaltic tuff + lava sheets in Iceland and Antarctica have been studied in detail and interpreted as subglacially emplaced (e.g. Walker and Blake, 1966; Bergh and Sigvaldason, 1991; Smellie et al., 1993; Loughlin, 2002; Smellie, 2008). Individual tuff + lava sheets can be voluminous, and for example the volumes of individual tuff + lava sheets of the Siða Formation in southern Iceland range from $<0.1 \mathrm{~km}^{3}$ to c. $31.4 \mathrm{~km}^{3}$, with 8 of the 14 mapped sheets having volumes over $10 \mathrm{~km}^{3}(\mathrm{Bergh}$ and Sigvaldason, 1991). It is noteworthy that tuff is almost always the dominant component in the Siða Formation tuff + lava sheets (Bergh and Sigvaldason, 1991). Furthermore, despite clear evidence of physical interactions between tuff and lava in these sheets, the tuff component represents an eruptive environment involving high fragmentation of magma, whereas the lava component represents a much less dynamic effusive eruptive environment. Finally, despite good descriptions of several tuff + lava sheets, it is apparent that the precise mechanisms of formation, transport, and deposition of tuff + lava sheets remain unclear (Banik et al., 2014). be subglacially emplaced, though likely candidates have been observed and briefly described at polygenetic Icelandic glaciovolcanic centres such as Eyjafjallajökull (Lithofacies association ' $\mathrm{H}$ ' of Loughlin, 2002) and Öraefajökull (Unit A of Stevenson et al., 2006). In contrast, several rhyolitic lavas that have been interpreted as lava sheets intruding the ice-edifice interface have been reported from Iceland (i.e. Prestahnúkur, McGarvie et al., 2006; Kerlingarfjöll, Stevenson et al., 2011; 
In a subglacial setting, the intrusion of a basaltic lava sheet into the interface between the ground and

159 the overlying ice has been modelled by Wilson and Head (2002). Two of their conclusions have high relevance to our study of Thórólfsfell: (1) the formation of basaltic lava sheets at the interface between the overlying ice and the bedrock is a straightforward process; and (2), cooling by the surrounding ice will almost never inhibit the emplacement and propagation of a basaltic lava sheet. It should be noted that the model of Wilson and Head (2002) used a horizontal ice-ground interface, and it is therefore reasonable to anticipate that on a sloping palaeosurface the emplacement of a basaltic lava sheet will be even more straightforward as it will be aided by both gravity and by the formation of larger meltwater drainage pathways on the downslope side of the volcanic edifice.

\subsection{The Thórólfsfell Tuya}

In this paper we present the first account of an unusual basaltic tuya from Iceland, Thórólfsfell. This is unique amongst studied Icelandic tuyas as it lacks the extensive fragment-dominated pahoehoe lavafed deltas thought to indicate significant meltwater accumulation at the eruption site (e.g. Skilling, 2009). Thórólfsfell offers new insights into basaltic tuya development in an environment that impedes meltwater accumulation, and we propose that, unusually, its lavas prograded beneath an ice roof.

Under the Russell et al., (2014) classification, Thórólfsfell plots as a well-drained/effusive eruption, however the lithofacies architecture at Thórólfsfell differs from those hypothesised. Thórólfsfell is new to the glaciovolcanic literature and in this paper we compare its deposits with other effusiondominated tuyas on a global context (e.g. The Table, Wilson et al., 2019). An ice thickness at the time of Thórólfsfell's eruption is estimated, an eruption age is estimated, and the hazards associated with a Thórólfsfell-type eruption are evaluated.

This paper should assist in the identification of other Thórólfsfell-type tuyas, and it also extends the spectrum of edifices formed during volcano-ice interactions.

Throughout this paper, the glacio-hydrological conditions at Thórólfsfell are referred to as 'welldrained', reflecting an environment in which abundant meltwater may be produced, but as this meltwater is swiftly moved away downslope via an effective subglacial drainage system, interactions 
between meltwater and eruptives is transient rather than sustained. We wish to emphasise that we have found no evidence whatsoever for the accumulation of a substantial body of meltwater at Thórólfsfell.

\section{GEOLOGICAL SETTING}

Thórólfsfell lies within the Icelandic Eastern Volcanic Zone (EVZ). Located at the edge of the Markarfljót valley, the tuya is constructed on the lowermost southern flank of Tindfjallajökull central volcano, whose summit is at 1,464 m amsl. (Fig. 1). Thórólfsfell, with an area of c. $8 \mathrm{~km}^{2}$, volume of c. $2.2 \pm 0.4 \mathrm{~km}^{3}$ (calculated from an average deposit thickness of $250 \mathrm{~m}$ ), and base-to-top height of c. $450 \mathrm{~m}$, is the largest of the tuyas either on or around the margins of the Tindfjallajökull central volcano (Moles et al., 2018). The Markarfljót river has incised the lowermost parts of the tuya, and extensive glacial erosion of its southern slopes relates to westward movement of an erosive, wet-based ice stream along the Markarfljót valley, with maximum ice thickness of c.1 km at the last glacial maximum (Bingham et al., 2003). Together, this erosion has provided good exposures of the tuyaconstructing lithofacies, and of the basement rocks, which are best seen on the eastern side and indicate a consistent c. $12^{\circ}$ average palaeosurface. This reflects the gently sloping southern flank of the Tindfjallajökull massif to the north.

The Thórólfsfell deposits rise c.425 m vertically above the lowermost point on its southern flank dominated by stacked lava lobes, but there is only c.50 m of relief on the north side. The vast majority of deposits emplaced at Thórólfsfell are to the south, resulting in the tuya having an asymmetrical profile (Fig. 1). Basement rocks are palagonitised massive and stratified tuffs and are heavily eroded. Exposed at both high and low elevations, these tuffs are in unconformable contact with Thórólfsfell rocks. A description and interpretation for the emplacement of these deposits is provided within Supplementary Material A.

\section{METHODS}


Fieldwork was conducted during May-June 2017. Field mapping techniques, together with analysis of

211

212 satellite imagery and digital elevation models (DEMs) were used to characterise the lithofacies architecture, create a geological map, and define stratigraphic successions. Samples were collected from each lithofacies type and the underlying basement for geochemical characterisation and comparison.

Whole-rock major and trace element abundances were determined from three samples: two from representative early and late erupted Thórólfsfell lavas and one from the basement. The whole-rock analyses were collected using a Panalytical PW2404 wavelength-dispersive sequential X-ray Fluorescence (XRF) instrument at the University of Edinburgh. Powdered samples were prepared as fused glass discs for major element analyses and pressed powder pellets for trace element analyses. Powders were heated at $1100^{\circ} \mathrm{C}$ for 20 minutes, with volatile loss on ignition (LOI) recorded. All normalised XRF data is presented in Table 1 and all data (raw and standard analyses) are presented within Supplementary Material B.

Fig. 2 displays Backscatter Electron (BSE) images from representative samples analysed by XRF, demonstrating characteristically fresh textures appropriate for whole-rock analyses. These images were taken using an accelerating voltage of $15 \mathrm{kV}$ on a JEOL 8600 wavelength-dispersive electron microprobe (EPMA) at the Research Laboratory for Archaeology and History of Art, University of Oxford.

\section{GEOCHEMISTRY}

We obtained whole-rock major and trace element analysis of three samples using $\mathrm{x}$-ray fluorescence (XRF). This was done for four simple reasons: (1) to establish the composition of the Thórólfsfell magma; (2) to establish whether or not the underlying basement to Thórólfsfell is (as field evidence indicates) an older and separate eruption; (3) to establish whether or not the Thórólfsfell magma was derived locally, and if so (4) what Thórólfsfell's likely relationship is to the nearby Tindfjallajökull volcanic system. 


\subsection{Major and trace elements (XRF)}

237

XRF analysis reveals that the two Thórólfsfell lava samples are basalts with $\mathrm{SiO}_{2}$ of 46.66 and 46.97 wt. \% and that the one sample from the underlying basement is a basalt with $47.16 \mathrm{wt} . \% \mathrm{SiO}_{2}$. Both Thórólfsfell samples are near-identical in major element concentrations, and relative to the basement they have noticeably lower $\mathrm{MgO}$ but higher $\mathrm{Na}_{2} \mathrm{O}$ and $\mathrm{K}_{2} \mathrm{O}$.

Notably, the trace element concentrations of Thórólfsfell and the underlying basement differ significantly, with the Thórólfsfell basalts being distinctively richer in $\mathrm{Ba}, \mathrm{Nb}, \mathrm{Zr}, \mathrm{Y}$, and $\mathrm{Sr}$.

All three samples are transitional alkali basalts, according to Jakobsson (1979), which are typical of basalts erupted in this flank (or off-rift) volcanic zone.

\subsection{Comparing Thórólfsfell with Tindfjallajökull}

We compare Thórólfsfell compositions with basalts erupted at Tindfjallajökull throughout its evolution, using data from Moles (2019). Fig. 3 shows a Total Alkali vs. Silica (TAS) plot and four selected bivariate plots $\left(\mathrm{SiO}_{2}\right.$ vs. $\mathrm{MgO}, \mathrm{TiO}_{2}$ vs. $\mathrm{CaO}, \mathrm{Sr}$ vs. $\mathrm{Zr}$, and $\mathrm{V}$ vs. Y) containing analyses of 34 Tindfjallajökull basalts, two Thórólfsfell basalts, and basalt from the underlying basement. On the TAS diagram, the Thórólfsfell lavas and basement fall within the Tindfjallajökull basalt field (Fig. 3a). A close geochemical association between Thórólfsfell and Tindfjallajökull is clear from other bivariate plots, although Thórólfsfell and/or basement samples can fall near (or define) the outer margins of the Tindfjallajökull field (e.g. for $\mathrm{TiO}_{2}$ vs. $\mathrm{CaO}$ and V vs. Y).

\subsection{Summary}

Addressing the four reasons outlined above for undertaking XRF analysis: (1) the Thórólfsfell magma is basaltic; (2) there is a clear geochemical difference between Thórólfsfell and the underlying basement, indicating eruption of different magma batches - and this corroborates field evidence indicating an older age, greater erosion, and different lithofacies for the underlying basement; (3) the transitional alkali basalt of Thórólfsfell is typical of basalts erupted in this volcanic zone, and so the magma was derived locally. Finally (4), whilst there is much geochemical similarity between the 
261 Thórólfsfell basalt and the Tindfjallajökull basalts, it is not possible to say whether Thórólfsfell is a

262 satellite vent of the Tindfjallajökull volcanic system or (like shield volcanoes and tuyas in the rift

263 zones) whether the Thórólfsfell tuya represents a separate magma batch unrelated to any nearby

264 volcanic system.

\section{LITHOFACIES}

267

We recognise three main lithofacies at Thórólfsfell, whose characteristics and contacts gradually change with elevation (Fig. 4; Table 2). Minor occurrences of glacial and fluvioglacial sediments are noted separately.

To facilitate communication, we have assigned three temporal Stages to the Thórólfsfell eruption - I (earliest) to III (latest); see Table 2. Stage I involved emplacement of the Lava Breccia Formation (LBF) onto the basement. In Stage II the Stacked Lava Formation (SLF) was emplaced, prior to Stage

273 III where the Upper Lava Formation (ULF) was emplaced until the end of the Thórólfsfell eruption.

274 Aside from minor sedimentary units, the tuya consists entirely of the above three lava-dominated 275 Formations (Stages I-III).

\section{LITHOFACIES DESCRIPTIONS AND INTERPRETATIONS}

278 Here the three Thórólfsfell lithofacies are described and interpreted. Thórólfsfell formations are 279 presented relative to their assigned eruptive stages from oldest to youngest.

\subsection{Stage I (Lava Breccia Formation, LBF)}

Description

282 The Lava Breccia Formation (LBF) is the lowermost lithofacies assigned to the Thórólfsfell eruptive 283 sequence (Table 2). In unconformable contact with the underlying basement, this lithofacies is c. 110 $m$ in thickness with a variable internal stratigraphy, comprising coarse and fine breccia interbeds 
alongside effused lava lobes (Fig. 5a,b). Coarser breccias (LBF-Cr) are massive, while finer breccia interbeds (LBF-Fi) preserve cross-stratification consistent with a southerly migration (Fig. 5c,c1).

These breccias are comprised of angular to sub-rounded grey lava clasts $(\leq 14 \mathrm{~cm})$ and devitrified finer lava fragments, respectively. Lava lobes ( $\leq 7 \mathrm{~m}$ thick) throughout the lithofacies are dominated by entablature jointing with closely-spaced fracture densities in the upper $80 \%$ of the lobe (Fig. $5 \mathrm{~d}$ ). Pseudopillow fractures also occur throughout and small $(<12 \mathrm{~cm}$ wide) colonnades are often present at their bases. Furthermore, some lavas exhibit $\leq 2 \mathrm{~m}$ wide cavities towards their bases and display more glassy surfaces than the rest of the lava (Fig. 5e). Longer and more rounded to tubular cavities are also present within some lobes, preserving lava drip structures and ridges on their smoother glassy surfaces (Fig. $5 \mathrm{f}$ - g2), although occasional smaller voids (up to $1 \mathrm{~m}$ ) display similar internal features.

Additionally, lava lobes within LBF are occasionally oversteepened $\left(>12^{\circ}\right.$ basement $)$ with occasional lava balls that have spalled from the main lobe. The lava is generally microcrystalline to glassy in appearance and a variety of lobe sizes and shapes occur, generally increasing in size with stratigraphic height (from c. $1 \mathrm{~m}$ to $\leq 5 \mathrm{~m}$ in diameter). Occasional squeeze-outs occur between fractures in the glassy carapaces of lavas (Fig. 5h).

\section{Interpretation}

We infer a higher effusion rate at the eruption onset, reflected by smaller lobes at the tuya base that increase in size towards the upper parts of the lithofacies, indicating a waning effusion rate with time (Rowland and Walker, 1990, Self et al., 1996). All interbeds throughout LBF are derived from lava effusion, with breccias resulting from disaggregation of the lobes. Palaeodirectional indicators (i.e. cross-stratification) within the finer breccias (LBF-Fi) suggest downslope migration of material aided by channelized meltwater pulses, evidenced by the progressive aggradation of fine lava fragment 'dunes'. In contrast, coarser lava breccias (LBF-Cr) were carried downslope when meltwater supply was enhanced.

The predominance of entablature jointing within LBF lava lobes indicates that the majority of upper lobe surfaces were rapidly chilled by meltwater (e.g. Moore and Schilling, 1973; Tuffen et al., 2002b; 
311 Forbes et al., 2014). Lower, underdeveloped basal colonnades indicate slower conductive cooling,

312 with less external coolant (e.g. DeGraff et al., 1989; Grossenbacher and McDuffie, 1995). The

313 presence of numerous pseudopillow fractures within lava carapaces has facilitated the cooling process

314 (Lescinsky and Fink, 2000).

315 Cavities within the base of some lavas are interpreted as ice-block meltout cavities, formed by the

316 incorporation of trapped ice blocks by the advancing lobes (e.g. Skilling, 2009). In contrast, larger and

317 more tubular cavities (as well as occasional metre-sized voids) featuring drip structures and lava

318 ridges are consistent with the drainage of ductile, molten lava from the lobe interiors. We infer the

319 chilled lava lobe carapaces fractured before lobe interiors had sufficient time to cool.

In summary, LBF represents Stage I of the Thórólfsfell eruption. This first phase was effusiondominated, with fragmental breccia interbeds resulting from fragmentation of the advancing lava which collected within depocenters of the irregular and dipping basement. A higher effusion rate is inferred in this initial phase of the eruption which may also have facilitated fragmentation and brecciation. We interpret this phase to represent a topography-filling stage, infilling the irregular basement onto which the lavas were emplaced. Breccia interbeds are the product of up-source fragmentation with coarser and finer breccias reflecting fluctuations in the availability and drainage of meltwater, aiding the downslope transport of material. Lava lobes within this Formation were able to extend from source to the lower flanks where a more continuous surface enabled emplacement with little to no disaggregation. Lava tongues and balls in the lower flanks of Thórólfsfell represent localised oversteepening prior to and during the onset of disaggregation.

\subsection{Stage II (Stacked Lava Formation, SLF)}

Description

The Stacked Lava Formation (SLF) is the most extensive and volumetrically dominant lithofacies at Thórólfsfell, with a thickness up to $240 \mathrm{~m}$ (Table 2). For mapping purposes, the contact with the underlying LBF is defined as the point where breccia interbeds of LBF no longer occur. SLF lobes are $\leq 11 \mathrm{~m}$ thick, comprising microcrystalline to glassy basalt, which dip generally c. $12^{\circ}$ to the south. 
Many SLF lobes can be traced laterally for up to c. $200 \mathrm{~m}$ (though 50 to $80 \mathrm{~m}$ is more typical) and produce a stack of lobes with distinctive sheet-like morphologies and low aspect ratios (Fig. 6a,b). fronts) and irregularities in their morphologies (up to $\leq 2 \mathrm{~m}$ higher points) within $\leq 25 \mathrm{~m}$ of lava fronts (Fig. 6c). Entablature is dominant at the flow fronts and dominate carapaces, however with increasing elevation, colonnades become more abundant and larger.

Most lavas are stacked atop one another, although occasionally lava autobreccias occur between lobes and near to their flow fronts (Fig. 6c, 6d). These are generally massive and are thickest towards the flow fronts, tapering in thickness with increased distance from the termini of the lobes. The autobreccias are colour graded away from the lava, from red to yellow/orange (Fig. 6d). Additionally, the stacked lava lobes recede in terms of their outflow distance with stratigraphic height, resulting in 'stepped tiering' amongst the tuya (see topographic profile in Fig. 4c).

Furthermore, the lowermost lava lobes within this lithofacies contain glassy cavities similar to those found in lithofacies LBF, of which some have irregular edges with sharp asperities. Larger cavities (>5 m) typically demonstrate more strongly developed colonnades around the void(s) within the main body of the flow. These cavities are situated towards the base of the lava lobes. Similar to LBF, elongate and tubular cavities preserving drip structures and lava stalactites are occasionally exposed within lobes, however these void sizes are smaller than in LBF, generally $<1 \mathrm{~m}$ in diameter.

Minor and localised outcrops of pillow lavas (SLF-PL) are occasionally present. These are typical rounded-oblate pillows and display glassy rinds and prismatic jointing radiating from core to rind. A thin brown, fine (glassy) matrix fills interstitial spaces between pillows.

SLF is interpreted to be a series of stacked lava lobes. Low-angle dips of their semi-planar bases are consistent with the $\mathrm{c} .12^{\circ}$ dip of the underlying basement. The emplaced lavas are likely to have been chilled by overlying ice and freely flowing meltwater to the south, responsible for entablaturedominated surfaces. Colonnades record a slower cooling regime within the interiors and bases. A 
decrease in entablature to colonnade ratio with elevation is representative of a 'drying-up' sequence

364

365 where coolant (i.e. meltwater) availability decreases with height due to a waning effusion rate throughout the eruption (i.e. increasingly less interaction between lava and ice resulting in less production of meltwater). Their sheet-like morphologies further suggest overlying ice was in close contact, or a host for the lava to intrude. In this model, the advancing lava lobes are hampered from progressing further downslope due to a narrowing of meltwater pathways - i.e. where the front of the lava lobe meets an ice barrier. This promotes preferential inflation of the front of the lava lobe, which will push upwards into the overlying ice, though the inflation rate will slow down. In addition to inflating upwards, the lava lobe front will propagate laterally along the boundary between the ice barrier and the edifice, driven both by the gravitational head of lava and the mechanical ease with which sheets/sills are predicted to move laterally (Wilson and Head, 2002). This process produces the distinctive sheet-like morphologies of many of the SLF lava lobes.

We interpret irregularities in lava morphologies $\leq 25 \mathrm{~m}$ behind lava fronts to further demonstrate lava inflated into the ice above after being halted by an ice barrier - with greatest effect closest to the lobe fronts.

Tapered breccias that are thickest beneath some lobe fronts are interpreted as autobreccias, derived from disaggregation of the advancing lava lobes. Their clast componentry, which matches that of the intact lava lobes themselves, is consistent with this interpretation. It is possible the tapering breccias are caused by a decreasing supply of lava, derived by in situ autobrecciation. Another possible explanation is that they were deposited against an ice barrier prior to being covered by the lava from which they were derived. In order to reach the barrier first, it is possible these breccias were carried by meltwater draining to the south, being halted at time one $\left(\mathrm{t}_{1}\right)$ against the ice. The parent lava then reached the autobreccia 'wedge' and overrode it at time two $\left(\mathrm{t}_{2}\right)$, until its advance was halted by the same ice barrier that ceased autobreccia transport. In an alternative scenario, the lava lobes may be partly intrusive at $\mathrm{t}_{2}$, exploiting space between the unstable lava breccia and the overlying ice, and locally burrowing within the autobreccias. The colour gradation in the autobreccias with distance 
from lavas is consistent with either model, suggesting the overriding lava baked the breccia, with heat intensity decreasing further from the autobreccia-lava contact.

391 The above models must permit effective drainage of meltwater underneath the ice barrier otherwise meltwater would also be trapped, forming a subglacial lake. If a subglacial lake had formed, the lava would start to form pillow lavas (e.g. Höskuldsson et al., 2006). Although rare, occasional pillow lavas (SLF-PL) are exposed within this lithofacies. We therefore suggest that during localised instances where effective drainage of meltwater temporarily ceased, small 'pockets' of pillow lavas formed within transient bodies of meltwater, until drainage resumed. The fine matrix coating pillows in SLF-PL is interstitial glass from the spalling of the expanding (glassy) pillow carapaces.

Moreover, glassy and tubular cavities within lava lobes are interpreted as ice-block meltout cavities and drainage features, respectively, similar to cavities within LBF. Ice-block meltout cavities within SLF are relatively larger and display a greater cooling effect on the surrounding lava (i.e. localised colonnades). We interpret this to be the result of larger ice blocks falling at higher elevations (due to thawing from emitted thermal energy), closer to the vent(s) and fracturing of occasional glassy carapaces, respectively.

In summary, SLF represents Stage II of the Thórólfsfell eruption. This phase remained effusiondominated, with lavas emplaced onto a largely stable c. $12^{\circ}$ slope formed by the underlying LBF deposits. Many SLF lavas were emplaced with sheet-like morphologies, due to hindered inflation and subsequent lateral exploitation at the ice-edifice interface. After becoming fully space-limited following inflation and lateral propagation, the lava eventually fed new lobes which overrode the previous flows. Autobreccias from some lavas cascaded down the edifice sides, assisted by meltwater, until abutting ice barriers and being overridden (and potentially partly intruded) by their parent lava. The series of stacked lava lobes were emplaced in conditions that permitted chilling of their upper surfaces by ice and/or transient meltwater. A decrease in entablature to colonnade ratios with stratigraphic height is further consistent with a waning effusion rate throughout the eruption. 
The Upper Lava Formation (ULF) has a minimum thickness of c.110 m (Table 2). For mapping

417 purposes, the SLF-ULF contact is defined by an up to 40:60 colonnade to entablature ratio within

418 lavas, as they display the strongest developed colonnades (Fig. 7a) of any of the lithofacies at

419 Thórólfsfell. Despite this, lava morphologies are the same as in SLF, occur as stacked lava lobes and are also dominated by entablature fracture densities for the bulk of this lithofacies (Fig. 7b,7c). Lobes are generally thicker, up to c. $20 \mathrm{~m}$ in thickness.

The uppermost (c. 10 to $20 \mathrm{~m}$ ) lavas of ULF are the exception to this and are completely devoid of entablature whatsoever. Lavas forming this upper surface of Thórólfsfell are sub-horizontal and display abundant rounded $(\leq 12 \mathrm{~mm})$ vesicles throughout and occasional pipe vesicles $(\leq 2 \mathrm{~cm})$ within lava flow bases. Colonnades account for close-to $100 \%$ of the fracture densities and they display clear polygonal geometries and well-formed chisel marks (striae).

The uppermost summit area also displays a high abundance of prominent low-angle and oval-shaped lava mounds, c.10-40 $\mathrm{m}$ in diameter. These have large and crudely-polygonal fractures which are oriented orthogonal to the curved upper surface of each lava mound (Fig. 7 e-g). On these lava mounds are abundant glacial striae, oriented in an east-west direction (Fig. 7d).

Minor outcrops of pillow lavas (ULF-PL) occur near the base of the ULF formation, close to the contact with SLF (Fig. 7h). These display the same characteristics as SLF-PL pillows, with glassy rinds, prismatic jointing, and a fine adhering matrix (Fig. 7i-j).

Interpretation

ULF represents the third and final stage of the Thórólfsfell eruption.

Apart from the uppermost c. 10 to $20 \mathrm{~m}$ comprising the summit, the bulk of this $\mathrm{c} .110 \mathrm{~m}$ thick lithofacies comprises stacked lava lobes with each lava displaying an upper entablature tier and a 438 lower colonnade tier (e.g. Fig.8c). Minor occurrences of pillow lavas and entablature-dominated lava 439 lobes, similar to those in Stage II, are also present. The above evidence suggests that coolant (i.e. 
meltwater) was available to interact with lavas during much of this final Stage of tuya formation,

441 though the thicker lava flows along with greater occurrences of their lower colonnades indicates a

442 decrease in meltwater abundance with elevation (e.g. Tuffen et al., 2002b; Smellie, 2006; Edwards et al., 2012; Stevenson et al., 2011).

The oval-shaped mounds that are restricted to the uppermost parts (c. 10 to $20 \mathrm{~m}$ ) of the tuya are interpreted as tumuli that have developed due to inflation of subaerial pahoehoe lavas. As the largerscale and crudely-polygonal fractures have developed orthogonal to the upper surface of the mounds, they present a gentle radiating appearance (see Fig. $7 \mathrm{~g}, \mathrm{~g} 1$ ). This geometrical relationship confirms that these mounds are not simply the products of glacial action (i.e. roche moutonnée). Instead, these mounds are subaerial tumuli from which the outermost fragile parts (e.g. pahoehoe ropes) have been removed by a minor amount of glacial erosion. These subaerial lavas display similar features (e.g. tumuli) to what has been observed at other subaerial lava caps on tuyas (e.g. Skilling, 2009).

In summary, ULF is the final effusion-dominated phase of tuya construction at Thórólfsfell, and within the uppermost part of ULF there is a transition from a subglacial to subaerial eruptive environment where the meltwater-cooled (entablature) lavas disappear and the subaerial pahoehoe tumuli appear. The limited extent of the subaerial part of ULF indicates a close association between the growing tuya and the enveloping ice until the very last part of the eruption.

\section{RELEVANT POST-ERUPTION FEATURES}

\subsection{Glacial Action}

The upper surfaces of Thórólfsfell's pahoehoe summit plateau are smooth and striated, with striae predominantly orientated east-to-west, indicating the flow direction of wet-based ice that once covered the summit of Thórólfsfell (section 6.3). This coincides with the orientation of the adjacent Markarfljót valley, and the inferred local ice flow direction during the Weichselian glaciation (Bingham et al., 2003). As tumuli at the summit of Thórólfsfell still exhibit significant relief and their internal geometry is intact, they have only been subject to minor glacial erosion. 


\subsection{Estimations of Ice Thickness}

467

The most prominent high land close to Thórólfsfell that would have been an ice accumulation area during the Weichselian, is the summit region of Tindfjallajökull central volcano (currently 1,464 m amsl.), lying c.10 km to the north-northeast (Moles, 2019). If Tindfjallajökull had been the major influence on ice movement in the area then the striations on the summit of Thórólfsfell (574 m amsl.) would be orientated northeast-southwest and not east-west. This is not what is observed. Instead, abundant east-west striae on the summit lavas (section 7.1) indicate that an ice stream filling the eastwest Markarfljót valley was the major influence on ice movement in the area (Bingham et al., 2003). Given that the summit of Thórólfsfell is currently at an elevation of $574 \mathrm{~m}$ amsl., the surface of the Markarfljót ice stream would have been at least $50 \mathrm{~m}$ higher than the summit (possibly up to $200 \mathrm{~m}$ thick), and so at Thórólfsfell this ice stream would have been c.3.2 km wide and at least $624 \mathrm{~m}$ thick.

In summary, whilst it is possible to provide a reliable estimate of minimum ice thickness at Thórólfsfell (i.e. an ice stream surface of at least $624 \mathrm{~m}$ amsl.), it is not possible to provide a maximum reliable estimate.

\subsection{Glacial Till}

A well-preserved blanket of diamict also drapes Thórólfsfell, which is unconsolidated to weakly consolidated and typically $\leq 1.5 \mathrm{~m}$ thick, although it locally reaches $4 \mathrm{~m}$. This poorly-sorted deposit is most clearly exposed on the southern (eroded) slopes of the tuya, dipping into eroded gullies, suggesting it was deposited after the glacial erosion event that affected the southern flanks. We interpret the diamict as a melt-out (glacial) till that represents the final stage of melting of the Weichselian ice sheet during the last deglaciation, which in this area would probably have been between $11.7 \mathrm{ka}$ and $9.5 \mathrm{ka}$ (Grosswald, 1980; Lundqvist, 1986).

\subsection{Estimation of relative eruption age}

We use three lines of evidence to suggest that Thórólfsfell erupted towards the end of the Weichselian: (1) the summit striations and their orientation; (2) the relatively minor erosion of the southern slopes of the tuya; and (3) deposition of a well-preserved blanket of meltout till. Formation 
of the tuya much earlier in the Weichselian would have resulted in more extensive erosion, especially of the flanks. The eruption clearly preceded deglaciation, otherwise sufficient ice would not have been available to form the abundant striae observed at the summit. It is tentatively suggested that Thórólfsfell erupted after the Last Glacial Maximum (c.25 ka) and probably between 20-15 ka.

\section{DISCUSSION}

\subsection{Eruption of Thórólfsfell}

Thórólfsfell has an unusual combination of lithofacies and a distinctively asymmetrical profile, both of which are very different to well-studied 'classic' basaltic tuyas such as Hlöðufell (Skilling, 2009). We compare Thórólfsfell and Hlöðufell from these two perspectives (Fig. 8).

The earliest-exposed Thórólfsfell volcanics are a series of breccias and water-cooled lavas (LBF) emplaced as an irregular blanket across a c. $12^{\circ}$ southerly-dipping basement. LBF are thickest where they infill hollows and thinnest (or absent) across topographic highs in the basement. The breccias derive from disaggregation of partly-quenched lava into blocks, with no evidence for magmatic fragmentation. Tuya construction at Thórólfsfell began with this topography-filling effusive lava and breccia phase (Stage I), with lavas and breccias travelling downslope for c. $1.5 \mathrm{~km}$ from the probable vent area. This contrasts strongly with the inferred early construction stage of 'classic' tuyas, where a pillow lava pile builds and is restricted to the immediate vent area (e.g. Skilling, 2009).

The LBF breccias require space for their transport and emplacement. It is not possible for these breccias to possess enough energy to melt overlying ice as a $\mathrm{c} .10 \mathrm{~cm}$ clast will reach thermal equilibrium in c.1000 seconds (Guðmundsson, 2003). The timescale of the breccia formation, downslope transportation and deposition will greatly exceed this timescale. We therefore suggest that meltwater pulses from higher (e.g. near-vent) elevations played a key role in melting subglacial pathways and creating the space for gravity-driven downslope breccia transport and deposition. 
516 A gradual transition occurs between the early erupted LBF lavas and breccias (Stage I) into the

517 volumetrically dominant lithofacies at Thórólfsfell - the Stacked Lava Formation (SLF, Stage II).

518 SLF comprises coherent and sheet-like lava lobes that also have ubiquitous water-cooled fractures on

519 their upper surfaces (entablature). Erosion reveals that beneath the thicker entablature carapaces, a

520 thin basal colonnade is developed within the interior of each lobe. These two contrasting cooling

521 regimes indicate a rapid cooling of the carapace by meltwater with the (entablature) cooling front

522 progressing from the outside of the lobe to the inside, whilst at the base of the lobe conductive cooling

523 produces a small colonnade that develops from the base upwards.

524 The SLF (Stage II) deposits are consistent throughout the eruption with evidence for decreasing 525 meltwater availability with stratigraphic height (i.e. gradually diminishing entablature). A waning

526 effusion rate has resulted in shorter outflow distances with height and a general increase in lobe size.

527 The SLF-ULF transition is again gradational, and its lavas have increasingly larger and more

528 dominant colonnades with height. The uppermost surfaces of ULF were emplaced subaerially,

529 displaying characteristic pahoehoe inflation (e.g. tumuli) and a lack of entablature. We interpret this

530 thin upper 'veneer' (up to $20 \mathrm{~m}$ ) of sub-horizontal lavas to represent the end of effusion from

531 Thórólfsfell and subsequently the end of the Thórólfsfell eruption.

532 A distinct difference between Thórólfsfell and other 'classic' basaltic tuyas is the lack of a lava-fed

533 delta and/or passage zone at the subaerial-subaqueous transition. Fig. 9 shows the lava lobe stack at

534 Thórólfsfell presented alongside a 'classic' tuya where lava-fed breccias are typically formed. The

535 lack of sustained meltwater accumulation surrounding the growing edifice at Thórólfsfell is

536 responsible for this difference in lithofacies. The 'stepped tiering' (as also seen in the cross section in

537 Fig. 4c) is a result of receding lavas due to a waning effusion rate. This further corroborates an

538 interpretation of a well-drained eruptive environment, as a slowing effusion rate into standing water

539 would result in pillow lavas forming at the edges of lavas lobes, where advancement is slower (e.g.

540 Hungerford et al., 2014). At Thórólfsfell no pillow lavas are observed at the edges of lava lobes

541 further indicating no significant meltwater accumulation. 
543 The mechanism we propose for lava lobe propagation involves advancing lobes exploiting a gap at the

544 ice-edifice interface. When forward progress is inhibited by the narrowing of the gap, the lava lobe 545 responds by inflating (Deschamps et al., 2014), leading both to lateral and vertical propagation along

546 the ice-edifice interface (c.f. Wilson and Head, 2002) and overlying ice, respectively. This

547 propagation is driven by the gravitational 'head' of lava from the vent area at higher elevations. The 548 invoked mechanism involves near-constant contact between the inflating lava carapace and ice, which 549 would enhance melting and meltwater release across the entire upper lava carapace, promoting rapid cooling and formation of the high-fracture-density cooling fractures, characteristic of entablature

551 (Forbes et al., 2014). Once crustal thickening rendered the lava lobe immobile and unable to

552 propagate further, localised breakouts could form if the lava pressure exceeded the carapace strength

553 (Deschamps et al., 2014).

This mechanism, because it involves persistent contact between lava and overlying ice, as ice-edifice lava sheets (McGarvie et al., 2007), will produce sizeable lava lobes, with broadly similar morphologies and cooling fracture patterns, across the growing volcanic pile, as inferred to have occurred from our observations.

The above model for lava lobe propagation beneath a persistent ice roof implies that the bulk of meltwater is locally produced by the contact between lava and ice. Given the palaeoslope, it could be assumed that the dominant meltwater source must have instead been at higher elevations to the northnortheast, as interpreted for Stage I of the eruption. Our observations of SLF and ULF (sections 6.2 and 6.3) however do not support this distal meltwater scenario as such a model would have entrained a proportion of the unconsolidated material (e.g. disaggregated lava fragments) which would have been transported and deposited as sedimentary interbeds draping the (SLF and ULF) lava lobes. These would be expected to thicken into hollows and depocenters. Instead, breccias are only occasionally found as autobreccias beneath lava lobe fronts, thinning up source. These do not occur beneath every

567 lava nor are found in topographic hollows at higher elevations. Additionally, this alternative scenario would result in emplacement of lavas in 'well-drained cavities' at the ice-edifice interface and any 
sediment-laden meltwater pulses from above would have preferentially flowed in the low areas between lava lobes and would therefore have chilled only their lower sides, leaving the upper surfaces to cool into air, in essentially subaerial conditions. Again, there is no evidence to suggest this.

572 Our model for predominantly locally produced meltwater results in consistent lava lobe cooling

573 throughout the bulk of the tuya. The consistency of features within the lavas at Thórólfsfell is remarkable, given their vertical and lateral growth, and evidences the persistent availability of coolant from a local meltwater source (c.f. rhyolitic lava lobes inferred to have quenched against ice walls at Bláhnúkur, Iceland; Tuffen et al. 2002b). Minor downslope meltwater runoff is responsible for occasional autobreccia 'wedges' and would have aided cavity widening by warm/hot meltwater thermally enlarging cavities.

The local ice thickness at the time of eruption is unknown but, as discussed in section 7.2, must have had a thickness of over $600 \mathrm{~m}$. The base of Thórólfsfell, where it meets the Markarfljót valley, is at c.140 m amsl., giving an ice thickness of $\geq 460 \mathrm{~m}$ over the lowest exposed part of Thórólfsfell. Lava lobes forming the stacked lavas therefore likely moved beneath thickening ice as they travelled south along the ice-edifice interface from a vent close to the summit. A gradational change in colonnade to entablature ratios with elevation further suggests the process of emplacement and meltwater generation was consistent throughout the eruption however thinning ice in the later stages of the eruption, coupled with the shorter outflow distances lavas exhibited due to a waning effusion rate with time were responsible for a decreasing availability of coolant (i.e. a 'drying up' sequence).

The only lavas at Thórólfsfell exhibiting 'classic' features of subaerially-erupted basaltic lava, with neither entablature nor evidence for confinement are at the uppermost surface of ULF and are interpreted to represent final effused lavas open to the atmosphere which signalled the end of the eruption. Fig. 10, alongside the interpreted glacio-hydrologic setting into which they were erupted. 
595 As previously discussed (Section 1.4), Thórólfsfell can be classified as an effusion-dominated tuya in 596 well-drained conditions under the Russell et al., (2014) classification scheme. Despite this, the 597 lithofacies observed at Thórólfsfell differ from those presented for tuyas with the same/similar glacio598 hydrologic conditions and eruption style. Russell et al., (2014) states that tuyas in these conditions and 599 demonstrating effusive activity will produce mostly subaerial lavas and a tephra-dominated base. 600 Contrastingly, Thórólfsfell's base is composed of lava, with the eruption beginning effusively. Its stacked lava lobes are subglacially emplaced, lacking subaerial features until the transition to subaerial emplacement within the uppermost lavas of ULF. The dipping basement and efficient drainage of meltwater has resulted in advancement of lava lobes under a persistent ice roof. Thórólfsfell therefore does not conform to current classification schemes that exist for tuyas. Belt, British Columbia, Canada. Although these share similar characteristics with Thórólfsfell, (e.g. stacked lavas), subaerial features in the upper surfaces of flows, horizontal columns and jointing patterns unrelated to palaeotopography are all lacking at Thórólfsfell. Additionally, edifice shapes contrast from Thórólfsfell's distinctively asymmetrical geometry. Similarly, recent work (Wilson et al., 2019) on The Table, British Columbia, Canada, share similarities with Thórólfsfell (e.g. exploitation of meltwater cavities) however are devoid of ice-contact features, due to formation of a quench breccia. Wilson et al., (2019) note that The Table was emplaced from dyke injection vertically, growing endogenously. Unlike Thórólfsfell, The Table's efficient drainage of meltwater along a persistent palaeoslope has had little effect on the types, distribution and architecture of the lithofacies. As the Table is the best-studied effusion dominated tuya in the literature, we compare and contrast Thórólfsfell with The Table in Table 3. Both The Table and Thórólfsfell highlight that

617 diversity exists within effusion-dominated tuyas and the processes involved in their eruption and subsequent formation of their lithofacies is more complex and varied than previously thought.

\subsection{Comparison with Icelandic subglacial sheet-like sequences}

620 As outlined in the Introduction (Section 1.3), the most detailed studies of suspected subglacial sheet-

621 like sequences include the voluminous (tuff dominated) tuff + lava sheets of the Siða Formation in 
southern Iceland (with average volumes up to $31.4 \mathrm{~km}^{3}$; Bergh \& Sigvaldason, 1991). Similar tuff +

623 lava sheet-like sequences occur at Eyjafjallajökull (e.g. Lithofacies C of Loughlin, 2002), but their

624 volumes are much smaller $\left(<0.6 \mathrm{~km}^{3}\right)$. The Siða Formation have six key differences with the subglacial lava lobe stack at Thórólfsfell: (1) the volumes of Siða tuff and lava sheets are at least two orders of magnitude greater than individual lava lobes at Thórólfsfell; (2) the along-strike dimensions of the Siða sheets are much greater, with individual sheets being at least $6 \mathrm{~km}$ long before exposure is lost beneath younger cover, whereas individual Thórólfsfell lava lobes are no longer than c.1.5 km (3) Siða tuff + lava sheets vary in thickness from 10 m to 220 m, whereas the Thórólfsfell lava lobes are much thinner, with thicknesses between approximately $7 \mathrm{~m}$ and $20 \mathrm{~m}$; (4) the Siða tuff + lava sheets occupy ancient valleys with kinematic indicators showing that they have moved down these valleys, whereas the Thórólfsfell lava lobes have not been confined by any palaeotopography, and instead have constructed a lava lobe stack on the downslope side of the tuya; (5) the Thórólfsfell lava lobes are much simpler, comprising just lava and minor associated breccias, whereas the Siða tuff + lava sheets are more complex and tuff-dominated; (6) the Thórólfsfell lava lobes are clearly part of a tuyabuilding eruption and the sources of the Siða sheets have not yet been identified.

637 Consequently, a key reason underpinning our claim that Thórólfsfell is a new type of glaciovolcano is the abundance of stacked lavas lobes with consistent features that we interpret to have been formed subglacially at the ice-edifice interface. These are integral to the formation of Thórólfsfell and reflect a sustained and consistent effusion of lava into the base of the overlying ice. downslope side, to emphasise that Thórólfsfell is not unique, Fig. 11 shows the Bláfell tuya presented alongside Thórólfsfell. Bláfell lies c. 5 km north of Thórólfsfell and (crucially) also sits on the c.12º sloping southern flank of the Tindfjallajökull central volcano. Bláfell is a well-preserved tuya of unknown age, which has an eroded but identifiable scoria cone at its summit, and which has a deeply eroded sector at its SE margin in which has exposed a stack of lava lobes that are remarkably similar to those at Thórólfsfell. Whilst Thórólfsfell is basalt and evidence suggests that the lava lobe stack was fed by pahoehoe lavas (e.g. by the presence of surface tumuli and occasional pillow lavas), 
Bláfell is basaltic andesite (Moles, 2019), and its lava lobe stack has clearly been fed by a'a lavas.

650 Despite differences in lava chemistry and flow types (i.e. pahoehoe vs. a'a), the strong similarity of

651 the lava lobes in both tuyas suggests a common mechanism involving consistent interactions between

652 downflowing lava and overlying ice that is independent of lava composition and rheology.

\section{8.5. Eruptive Hazards from a Thórólfsfell-type eruption}

654 As large volumes of meltwater can be produced during subglacial basalt eruptions (Wilson and Head, 655 2002), the storage, transport, and release of this meltwater is of key importance in evaluating potential 656 hazards (Wilson et al., 2019).

657 Where meltwater is stored in large volumes close to the eruption site, which is inferred for large tuya658 forming eruptions within regional ice sheets, the sudden release of this meltwater could have

659

660

661

662

663

664

665

666

667

668

669

670

671

672

673 catastrophic effects. Even the sudden release of more modest volumes of meltwater, such as from Gjálp eruption in 1996 and from Grímsvötn in 2004, can result in substantial infrastructure damage, and would likely have led to fatalities if evacuation and road closures had not been actioned.

At Thórólfsfell, the strong evidence for no significant accumulation of substantial volumes of meltwater and continued efficient drainage of meltwater after transient interactions with freshly emplaced lava suggests a Thórólfsfell-type eruption on the ice covered sloping flanks of a larger volcanic complex, would permit persistent escape of meltwater to the ice margin, with occasional surges related to changes in ice melting rate or temporary backing-up of meltwater in the subglacial drainage system. In short, this continuous escape of meltwater from the eruption site would greatly reduce the hazards from glacial outburst floods (jökulhlaups).

\section{CONCLUSIONS}

1. Thórólfsfell is a distinctively asymmetrical basaltic tuya that erupted onto a basement that was dipping at an angle of $c .12^{\circ}$; the preferential construction of the tuya in the down-dip direction is the cause of the marked asymmetry. 
2. Thórólfsfell only shares two similar features with other basaltic tuyas: (1) a sub-horizontal top comprising subaerial lavas; and, (2) a positive relief - a result of upwards growth and construction due to confinement by encircling ice.

678

3. There is zero evidence for the presence of a substantial, sustained, and stable meltwater lake encircling the growing Thórólfsfell tuya. As such a lake is a necessary for the construction of a pahoehoe lava-fed delta, and Thórólfsfell does not have one, Thórólfsfell therefore lacks both a lava-fed delta and a passage zone.

4. Thórólfsfell is constructed from a combination of lithofacies that have not previously been described elsewhere, and thus we consider Thórólfsfell to be a new type of basaltic glaciovolcano.

686

5. This combination of lithofacies is unusual and is a product of the following interacting factors:

- A basement dipping at an angle of c. $12^{\circ}$.

- An eruption that involved only the effusion of lava (i.e. no explosive magmatic fragmentation occurred).

- A close and consistent connection between effusing lava lobes and confining ice (crucially, the ice above the lava lobes), which led to lava lobes at any given elevation experiencing near-uniform drenching by meltwater.

- Rapid drainage of meltwater away from source zones, with in-transit meltwater being responsible for the rapid cooling of freshly-emplaced and part-cooled lavas, and with meltwater eventually escaping the edifice into an efficient subglacial drainage system.

- A waning effusion rate, which led to a gradual reduction in the cooling of lavas by meltwater with elevation, ultimately resulting in a thin stack of subaerial pahoehoe lavas erupted at the very summit of the tuya. 
705

706

707

708

709

710

711

712

713

714

715

716

717

718

719

720

721

722

723

724

6. A Thórólfsfell-style eruption is of minor concern from a hazard perspective as rapid and steady meltwater drainage away from the eruption site is anticipated, and this would prevent the accumulation of meltwater that is required for high-magnitude and potentially destructive glacial outburst floods (i.e. jökulhlaups).

7. This descriptive account of Thórólfsfell, a new type of basaltic glaciovolcano, provides a number of criteria that will aid in the identification of other Thórólfsfell-type tuyas on Earth and Mars that have yet to be discovered.

\section{ACKNOWLEDGEMENTS}

We wish to thank Rannsóknamiðstöð for granting permission to conduct research at Thórólfsfell.

Field assistance from Josh Weaver and Heather Lagan was invaluable. AGEH acknowledges support from the Elspeth Matthews Fund of the Geological Society of London and a bursary from the Lancaster Environment Centre, Lancaster University. DMcG wishes to thank Björn Oddsson of Feltfelagið for excellent $4 \mathrm{x} 4$ vehicle support. HT was supported by a Royal Society University Research Fellowship. We wish to thank Victoria Smith for time on the Electron Microprobe at Oxford University and Alan Hastie and Daniel Cox for insightful discussions and input regarding the geochemical datasets. We also thank Pórdís Högnadóttir and Joaquín Muñoz-Cobo Belart for providing a DEM of the region as well as Jonathan Moles for many discussions about Thórólfsfell and Tindfjallajökull. We also with to thank Paul and Judi at Fljótsdalur Hostel, and Anna and Kelly (landowners) for support with the fieldwork. Constructive comments from two anonymous reviewers greatly improved this manuscript. Editorial handling from Kelly Russell was impeccable. 
Banik, T.J., Wallace, P.J., Höskuldsson, Á., Miller, c.F., Bacon, c.R. and Furbish, D.J., 2014. Magma-ice-sediment interactions and the origin of lava/hyaloclastite sequences in the Síða formation, South Iceland. Bulletin of Volcanology, 76(1), p.785.

Bergh, S.G. and Sigvaldason, G.E., 1991. Pleistocene mass-flow deposits of basaltic hyaloclastite on a shallow submarine shelf, South Iceland. Bulletin of Volcanology, 53(8), pp.597-611.

Bingham, R.G., Hulton, N.R. and Dugmore, A.J., 2003. Modelling the southern extent of the last Icelandic ice-sheet. Journal of Quaternary Science: Published for the Quaternary Research Association, 18(2), pp.169-181.

DeGraff, J.M., Long, P.E. and Aydin, A., 1989. Use of joint-growth directions and rock textures to infer thermal regimes during solidification of basaltic lava flows. Journal of Volcanology and Geothermal Research, 38(3-4), pp.309-324.

Di Traglia, F., Nolesini, T., Solari, L., Ciampalini, A., Frodella, W., Steri, D., Allotta, B., Rindi, A., Marini, L., Monni, N. and Galardi, E., 2018. Lava delta deformation as a proxy for submarine slope instability. Earth and Planetary Science Letters, 488, pp.46-58.

Deschamps, A., Grigné, c., Le Saout, M., Soule, S.A., Allemand, P., Van Vliet-Lanoe, B. and Floc'h, F., 2014. Morphology and dynamics of inflated subaqueous basaltic lava flows. Geochemistry, Geophysics, Geosystems, 15(6), pp.2128-2150.

Edwards, B.R, Magnússon, E., Thordarson, T., Guđmundsson, M.T., Höskuldsson, A., Oddsson, B. and Haklar, J., 2012. Interactions between lava and snow/ice during the 2010 Fimmvörðuháls eruption, south-central Iceland. Journal of Geophysical Research: Solid Earth, 117(B4).

Edwards, B.R. and Russell, J.K., 2002. Glacial influences on morphology and eruptive products of Hoodoo Mountain volcano, Canada. Geological Society, London, Special Publications, 202(1), pp.179-194.

Forbes, A.E.S, Blake, S. and Tuffen, H., 2014. Entablature: fracture types and mechanisms. Bulletin of Volcanology, 76(5), p.820. 
Grossenbacher, K.A. and McDuffie, S.M., 1995. Conductive cooling of lava: columnar joint diameter and stria width as functions of cooling rate and thermal gradient. Journal of volcanology and geothermal research, 69(1-2), pp.95-103.

Grosswald, M.G., 1980. Late Weichselian ice sheet of northern Eurasia. Quaternary Research, 13(1), pp.1-32.

Gudmundsson, M.T., 2003. Melting of ice by magma-ice-water interactions during subglacial eruptions as an indicator of heat transfer in subaqueous eruptions. GEOPHYSICAL MONOGRAPHAMERICAN GEOPHYSICAL UNION, 140, pp.61-72.

Gumundsson, M.T., 2005. 6. Subglacial volcanic activity in Iceland. In Developments in quaternary sciences (Vol. 5, pp. 127-151). Elsevier.

Head, J.W. and Wilson, L., 2002. Mars: a review and synthesis of general environments and geological settings of magma-H2O interactions. Geological Society, London, Special Publications, 202(1), pp.27-57.

Hickson, c.J., 2000. Physical controls and resulting morphological forms of Quaternary ice-contact volcanoes in western Canada. Geomorphology, 32(3-4), pp.239-261.

Höskuldsson, A., Sparks, R.S. and Carroll, M.R., 2006. Constraints on the dynamics of subglacial basalt eruptions from geological and geochemical observations at Kverkfjöll, NE-Iceland. Bulletin of Volcanology, 68(7-8), p.689.

Hungerford, J.D., Edwards, B.R., Skilling, I.P. and Cameron, B.I., 2014. Evolution of a subglacial basaltic lava flow field: Tennena volcanic center, Mount Edziza volcanic complex, British Columbia, Canada. Journal of Volcanology and Geothermal Research, 272, pp.39-58.

Jakobsson, S.P. and Gudmundsson, M.T., 2008. Subglacial and intraglacial volcanic formations in Iceland. Jökull, 58, pp.179-196.

Jakobsson, S.P., 1979. Petrology of recent basalts of the Eastern Volcanic Zone, Iceland. 
774 Kelman, M.c., Russell, J.K. and Hickson, c.J., 2002a. Effusive intermediate glaciovolcanism in the

775 Garibaldi volcanic belt, southwestern British Columbia, Canada. Geological Society, London, Special 776 Publications, 202(1), pp.195-211.

777 Kelman, M.c., Russell, J.K. and Hickson, c.J., 2002b. Glaciovolcanism at ember ridge, Mount Cayley

778 volcanic field, southwestern British Columbia. Natural Resources Canada, Geological Survey of

779 Canada.

780 Lescinsky, D.T. and Fink, J.H., 2000. Lava and ice interaction at stratovolcanoes: use of characteristic

781 features to determine past glacial extents and future volcanic hazards. Journal of Geophysical

782 Research: Solid Earth, 105(B10), pp.23711-23726.

783 Loughlin, S.c., 2002. Facies analysis of proximal subglacial and proglacial volcaniclastic successions at the Eyjafjallajökull central volcano, southern Iceland. Geological Society, London, Special Publications, 202(1), pp.149-178.

Lundqvist, J., 1986. Late Weichselian glaciation and deglaciation in Scandinavia. Quaternary Science Reviews, 5, pp.269-292.

Magnússon, E., Pálsson, F., Björnsson, H. and Guðmundsson, S., 2012. Removing the ice cap of Öræfajökull central volcano, SE-Iceland: mapping and interpretation of bedrock topography, ice volumes, subglacial troughs and implications for hazards assessments. Jökull, 62, pp.131-150. Journal of Science, 245(9), pp.560-570. 
McGarvie, D., Stevenson, J.A., Burgess, R., Tuffen, H. and Tindle, A.G., 2007. Volcano-ice interactions at Prestahnúkur, Iceland: rhyolite eruption during the last interglacial-glacial transition. Annals of Glaciology, 45, pp.38-47.

McGarvie, D.W., Burgess, R., Tindle, A.G., Tuffen, H. and Stevenson, J.A., 2006. Pleistocene rhyolitic volcanism at Torfajökull, Iceland: eruption ages, glaciovolcanism, and geochemical evolution. Jökull, 56, pp.57-75.

Moles, J.D., 2019. Volcanic Archives of Past Glacial Environments: Tindfjallajökull Volcano, Iceland (Doctoral dissertation, The Open University).

Moles, J.D., McGarvie, D., Stevenson, J.A. and Sherlock, S.c., 2018. Geology of Tindfjallajökull volcano, Iceland. Journal of Maps, 14(2), pp.22-31.

Moore, J.G. and Jackson, M.D., 2020. Observations on the structure of Surtsey. Surtsey Research, 14, pp.33-45.

Moore, J.G. and Schilling, J.G., 1973. Vesicles, water, and sulfur in Reykjanes Ridge basalts. Contributions to Mineralogy and Petrology, 41(2), pp.105-118.

Pálmason, G. and Saemundsson, K., 1974. Iceland in relation to the Mid-Atlantic Ridge. Annual review of earth and planetary sciences, 2(1), pp.25-50.

Pedersen, G.B.M., Höskuldsson, A., Dürig, T., Thordarson, T., Jonsdottir, I., Riishuus, M.S., Óskarsson, B.V., Dumont, S., Magnússon, E., Gudmundsson, M.T. and Sigmundsson, F., 2017. Lava field evolution and emplacement dynamics of the 2014-2015 basaltic fissure eruption at Holuhraun, Iceland. Journal of Volcanology and Geothermal Research, 340, pp.155-169.

Räsänen, M.E., Huitti, J.V., Bhattarai, S., Harvey III, J. and Huttunen, S., 2015. The SE sector of the Middle Weichselian Eurasian Ice Sheet was much smaller than assumed. Quaternary Science Reviews, 122, pp.131-141. 
821 Subglacial volcanic activity above a lateral dyke path during the 2014-2015 Bárdarbunga-Holuhraun 822 rifting episode, Iceland. Bulletin of Volcanology, 79(6), p.38.

823 Rowland, S.K. and Walker, G.P.L., 1990. Pahoehoe and aa in Hawaii: volumetric flow rate controls 824 the lava structure. Bulletin of Volcanology, 52(8), pp.615-628.

825 Russell, J.K., Edwards, B.R., Porritt, L. and Ryane, c., 2014. Tuyas: a descriptive genetic

826 classification. Quaternary Science Reviews, 87, pp.70-81.

827 Russell, J.K., Hickson, c.J. and Andrews, G., 2007. Canadian Cascade volcanism: Subglacial to 828 explosive eruptions along the Sea to Sky Corridor, British Columbia. Floods, Faults, and Fire: 829 Geological Field Trips in Washington State and Southwest British Columbia: Geological Society of 830 America Field Guide, 9, pp.1-29. Finnemore, S., 1996. A new model for the emplacement of Columbia River basalts as large, inflated pahoehoe lava flow fields. Geophysical Research Letters, 23(19), pp.2689-2692.

Skilling, I.P., 2009. Subglacial to emergent basaltic volcanism at Hlöðufell, south-west Iceland: a history of ice-confinement. Journal of Volcanology and Geothermal Research, 185(4), pp.276-289.

837 Smellie, J.L. and Skilling, I.P., 1994. Products of subglacial volcanic eruptions under different ice 838 thicknesses: two examples from Antarctica. Sedimentary Geology, 91(1-4), pp.115-129.

839 Smellie, J.L., 2006. The relative importance of supraglacial versus subglacial meltwater escape in 840 basaltic subglacial tuya eruptions: an important unresolved conundrum. Earth-Science Reviews, 74(3841 4), pp.241-268. of Quaternary Science. Elsevier, Amsterdam, pp. 784-798. 
Smellie, J.L., 2008. Basaltic subglacial sheet-like sequences: evidence for two types with different

845 implications for the inferred thickness of associated ice. Earth-Science Reviews, 88(1-2), pp.60-88.

846 Smellie, J.L., Hole, M.J. and Nell, P.A.R., 1993. Late Miocene valley-confined subglacial volcanism

847 in northern Alexander Island, Antarctic Peninsula. Bulletin of Volcanology, 55(4), pp.273-288.

848 Smellie, J.L., Walker, A.J., McGarvie, D. and Burgess, R., 2016. Complex circular subsidence

849 structures in tephra deposited on large blocks of ice: Varða tuff cone, Öræfajökull, Iceland. Bulletin of 850 volcanology, 78(8), pp.1-21.

851 Stevenson, J.A., Gilbert, J.S., McGarvie, D. and Smellie, J.L., 2011. Explosive rhyolite tuya

852 formation: classic examples from Kerlingarfjöll, Iceland. Quaternary Science Reviews, 30(1-2),

853 pp.192-209.

854 Stevenson, J.A., McGarvie, D.W., Smellie, J.L. and Gilbert, J.S., 2006. Subglacial and ice-contact

855 volcanism at the Öræfajökull stratovolcano, Iceland. Bulletin of volcanology, 68(7-8), pp.737-752.

856 Stevenson, J.A., Smellie, J.L., McGarvie, D., Gilbert, J.S. and Cameron, B.I., 2009. Subglacial

857 intermediate volcanism at Kerlingarfjöll, Iceland: magma-water interactions beneath thick

858 ice. Journal of Volcanology and Geothermal Research, 185(4), pp.337-351.

859 Thordarson, T. and Larsen, G., 2007. Volcanism in Iceland in historical time: Volcano types, eruption

860 styles and eruptive history. Journal of Geodynamics, 43(1), pp.118-152.

861 Tribble, G.W., 1991. Underwater observations of active lava flows from Kilauea volcano, Hawaii.

862 Geology 19, 633-636

863 Tuffen, H. and Castro, J.M., 2009. The emplacement of an obsidian dyke through thin ice:

864 Hrafntinnuhryggur, Krafla Iceland. Journal of Volcanology and Geothermal Research, 185(4),

865 pp.352-366.

866 Tuffen, H., 2007. Models of ice melting and edifice growth at the onset of subglacial basaltic

867 eruptions. Journal of Geophysical Research: Solid Earth, 112(B3). 
Tuffen, H., McGarvie, D., Gilbert, J.S. and Pinkerton, H., 2002a. Physical volcanology of a subglacial-to-emergent rhyolitic tuya at Rauðufossafjöll, Torfajökull, Iceland. Geological Society, London, Special Publications, 202(1), pp.213-236.

Tuffen, H., Pinkerton, H., McGarvie, D. and Gilbert, J.S., 2002b. Melting of the glacier base during a small-volume subglacial rhyolite eruption: evidence from Bláhnúkur, Iceland. Sedimentary Geology, 149(1-3), pp.183-198.

Turney, c.S., Jones, R.T., Phipps, S.J., Thomas, Z., Hogg, A., Kershaw, A.P., Fogwill, c.J., Palmer, J., Ramsey, c.B., Adolphi, F. and Muscheler, R., 2017. Rapid global ocean-atmosphere response to Southern Ocean freshening during the last glacial. Nature communications, 8(1), pp.1-9.

Walker, A.J., 2011. Rhyolite Volcanism at Rfajkull Volcano, SE Iceland - a window on quaternary climate change.

Walker, G.P.L. and Blake, D.H., 1966. The formation of a palagonite breccia mass beneath a valley glacier in Iceland. Quarterly Journal of the Geological Society, 122(1-4), pp.45-58.

Weaver, J., Eggertsson, G.H., Utley, J.E., Wallace, P.A., Lamur, A., Kendrick, J.E., Tuffen, H., Markússon, S.H. and Lavallée, Y., 2020. Thermal liability of hyaloclastite in the Krafla geothermal reservoir, Iceland: the impact of phyllosilicates on permeability and rock strength. Geofluids, 2020.

Wilson, A.M., Russell, J.K. and Quane, S.L., 2019. The Table, a flat-topped volcano in southern British Columbia: Revisited. American Journal of Science, 319(1), pp.44-73.

Wilson, L. and Head, J.W., 2002. Heat transfer and melting in subglacial basaltic volcanic eruptions: implications for volcanic deposit morphology and meltwater volumes. Geological Society, London, Special Publications, 202(1), pp.5-26.

\section{FIGURE AND TABLE CAPTIONS}

\section{(in order presented in the manuscript)}


Fig. 1. (a) Map of mainland Iceland showing the distribution of the main zones of active volcanism (EVZ, WVZ, NVZ and SVB), defined by Sæmundsson (1979) where rocks are dated at <0.8 Ma. Major glaciers are superimposed showing current regions of active glaciovolcanism. (b) Digital Elevation Model (DEM) of Thórólfsfell in relation to surrounding central volcanoes, Tindfjallajökull and Eyjafjallajökull. The location of Bláfell (another effusion-dominated tuya) is also highlighted (c) Drone image displaying the asymmetrical morphology of Thórólfsfell from the east and its location with respect to the Markarfljót valley.

Table 1. Whole-rock (XRF) major and trace element compositions from Thórólfsfell, South Iceland. To account for a variety in hydration and for comparative purposes, major element concentrations are normalised to a $100 \%$ volatile free basis.

Fig, 2. Backscatter Electron (BSE) images of samples analysed for their geochemical composition. (ac) Fragments from the basaltic tuff basement below Thórólfsfell. Glass is altered and the groundmasses are microlite rich, dominated by feldspar laths. (d-f) Fragments of lavas from Thórólfsfell analysed by XRF techniques. Lavas are glassy with a high abundance of microlites, dominated by feldspar laths.

Fig. 3. Selected geochemical plots demonstrating the composition of Thórólfsfell and its basement in relation to basalts from Tindfjallajökull (Moles, 2019). (a) Total Alkali vs. Silica (TAS) diagram showing all geochemical data in relation to compositional fields. All are basalts and geochemical fields have been defined for both Thórólfsfell and Tindfjallajökull volcanoes. These show overlap. Note: the Tindfjallajökull geochemical field is defined by Moles (2019). (b-c) Selected major element bivariate plots displaying Thórólfsfell samples alongside Tindfjallajökull data points. (d-e) Selected trace element bivariate plots displaying Thórólfsfell samples alongside Tindfjallajökull data points. 
918 Fig. 4. (a) Generalized Vertical Section (GVS) of the lithofacies at Thórólfsfell defined in this study.

919 Unit thicknesses have been determined using the calculations outlined in Table 2. (b) Geological Map 920 of Thórólfsfell displaying the distribution of the lithofacies, graphically presented in the GVS. The

921 SLF-ULF contact is defined by a general change in fracture densities of lavas, marking the transition 922 to lavas which can exhibit a colonnade to entablature ratio of 40:60. The LBF-SLF contact is defined 923 by a generalized interpretation of a lack of breccia interbeds. Note: all contacts are gradational and are generalized for mapping purposes. (c) Schematic cross section through Thórólfsfell along line of section A-A', marked on the Geological Map.

Table 2. Table of lithofacies codes, calculated unit thicknesses, descriptions, eruption stages and generalised emplacement mechanism for the effusive lithofacies at the Thórólfsfell basaltic tuya, south Iceland.

Fig. 5. Photographs of features associated with the Lava Breccia Formation (LBF). (a) Drone image of the lowermost exposure of Thórólfsfell, dissected by glacial erosion in the Markarfljót valley revealing the stacked lava lobes observed in LBF with variable interbeds of fine and coarse breccias. (b) Photograph displaying the outcropping of lava lobes and breccias interbeds. (c) Photograph displaying the localised complexities in the stratigraphy of LBF, in this case revealing a lava breccia from disaggregation of lava, overlain by finer and coarser lava-fragment interbeds, topped by a lava with underlying autobreccia. (c1) Photograph displaying cross-stratification preserving a southerly migration of fine material in interbed LBF-Fi (d) A valley exposing the stratigraphy of LBF and the lava lobes and coarser lava-fragment interbeds that comprise the lithofacies (e) Inferred ice-block meltout cavity from incorporation of a rafted chunk of ice amongst the lava (Skilling, 2009). A change in fracture density surrounds the feature, indicating the ice prolonged the cooling of the lava in direct contact with the block. (f) Photograph displaying the broken carapace of a lava lobe, revealing 
its interior (g) A close-up image of the exposed interior of the lobe in f. (g1) A close-up image of lava

944 drip structures preserved on the roof of the drained lava lobe interior in g. (g2) A close-up image of

945 the polygonal cooling cracks and preserved lava drips on the wall of the drained lava lobe interior in

946 g. (h) Photograph displaying a glassy squeeze out between lavas and breccias of LBF.

948 Fig. 6. Photographs of features within the Stacked Lava Formation (SLF). (a) Photograph looking to the east across two valleys carved into Thórólfsfell. The valleys display multiple stacked lava lobes which comprise SLF. These are extensive and laterally traceable for tens of metres. (b) Drone image of Thórólfsfell looking to the north. The image shows the lava lobes and sheets of which most of the tuya is formed. (c) An example of a lava lobe flow front which is interpreted to have become overthickened by inflation caused by the chilling and stoppage of the advancing flow by an ice barrier. The autobreccia directly below the flow front is also overthickened due to the collection of the breccia from higher elevations, washed down in meltwater pulses. The flow dramatically thins within $\leq 5 \mathrm{~m}$ of the flow front, localised inflation features can be seen. (d) An example of the baking of the underlying autobreccia by the overlying lava or by part intrusion by the lava. A red colouration is noticeable in the closest to the contact, with a transition to brown with increased distance from the lava.

Fig. 7. Photographs and interpretive cartoons of features and emplacement mechanisms associated with the Upper Lava Formation (ULF). (a) Colonnades within a lava of ULF. (b) Example of lobes directly below the summit lava cap. (c) Lava demonstrating basal colonnade and thick entablature tier above, with the entablature upper tier of an earlier lava below. (d) The upper part of the lava cap mildly eroded by glacial action. Glacial striations (oriented east to west) are highlighted by white dashed lines. (e) A subaerial pahoehoe tumulus standing as a prominent feature atop the upper surface of the lava cap - large and crudely polygonal cooling fractures are evident. (f) Close-up photograph of the tumulus in e. Valley-parallel (E-W) glacial striations indicate glacial erosion (see also d above). 
(g) Photograph of a tumulus with a geologist for scale. (g1) Interpretative sketch of g. Highlighted features include the domed morphology, glacial striations, large and crude polygonal cooling cracks, and regions where glassy squeeze-outs are common. (h) Small and localised pillow lava pile within ULF. (i) Junction between pillow carapaces (i1) Close-up image of i. (j) Fine adhering sediment to pillow rinds. (j1) Close-up image of j.

Fig. 8. Schematic illustrations of volcanic lithofacies and lithofacies associations at a 'classic tuya' compared with Thórólfsfell, partly modified from Jackobsson and Gudmundsson, 2008. On the left is a 'classic' tuya (exampled by Hlöðufell, Iceland) and on the right is Thórólfsfell. The two top rows display schematic illustrations and example photos of both tuyas in anterior view, with the photographs both taken with a view from the south. The two lower rows again display the same two tuyas, however illustrated and photographed from the lateral perspective. Diagrams are schematic and do not accurately portray the field image provided. Common lithofacies types between the two examples are displayed in the same colour. All lithofacies are annotated and lithofacies codes for Thórólfsfell displayed.

Fig. 9. A schematic comparison between the emplacement environment and subsequent lithofacies architectures at a classic' tuya compared with Thórólfsfell. The stacked lava lobes at Thórólfsfell are presented alongside the lava-fed deltas that typically form at 'classic' tuyas. The 'classic' tuya diagram is modified from Russell et al., (2014) and demonstrates dipping breccia-dominated lava-fed deltas at the edge of the growing edifice as the result of lava effusion into accumulated meltwater (meltwater moat). A passage zone location is marked, however subaerial lavas have been omitted for both tuya types to provide clarity. In contrast, Thórólfsfell demonstrates stacked lava lobes emplaced into a well-drained subglacial environment. Lavas have a gradually increasing colonnade to entablature ratios with stratigraphic height and receding outflow distances which we interpret is a result of waning effusion rate. Features throughout the stacked lava lobes are consistent throughout 
995

996

997

998

999

1000

1001

1002

1003

1004

1005

1006

1007

1008

1009

1010

1011

1012

1013

1014

the tuya. Both tuyas display the morphology of previously constructed phases, relationships to adjoining ice and the inferred bedrock orientation.

Fig. 10. Schematic cartoons of the interpreted glacio-hydrologic setting at Thórólfsfell and the dominant processes involved in the emplacement of the effusion-dominated lithofacies. (a) 3D box diagram providing an interpretation of the glacio-hydrologic conditions when Thórólfsfell was erupted. (b-d) Interpretations of the main eruptive processes involved in Stages I-III of the Thórólfsfell eruption.

Table 3. Table 3. Comparison between the eruptive, glacio-hydrologic and dynamic process at Thórólfsfell (This Study) and The Table (Wilson et al., 2019).

Fig. 11. A comparison between Thórólfsfell and the nearby Bláfell tuya. Photographs showing the edifice highlight that the tuyas are constructed of different lava types (pahoehoe and a'a, respectively) however both comprised of stacked lava lobes. Edifice features and their profiles are compared via simplified maps of the two volcanoes. Key features of Bláfell and the defined lava cap of Thórólfsfell are taken from Moles et al., (2018). Sketch profiles highlight that both tuyas display a persistent slope to the south. Images of the lava lobes are provided for comparative purposes. 
A
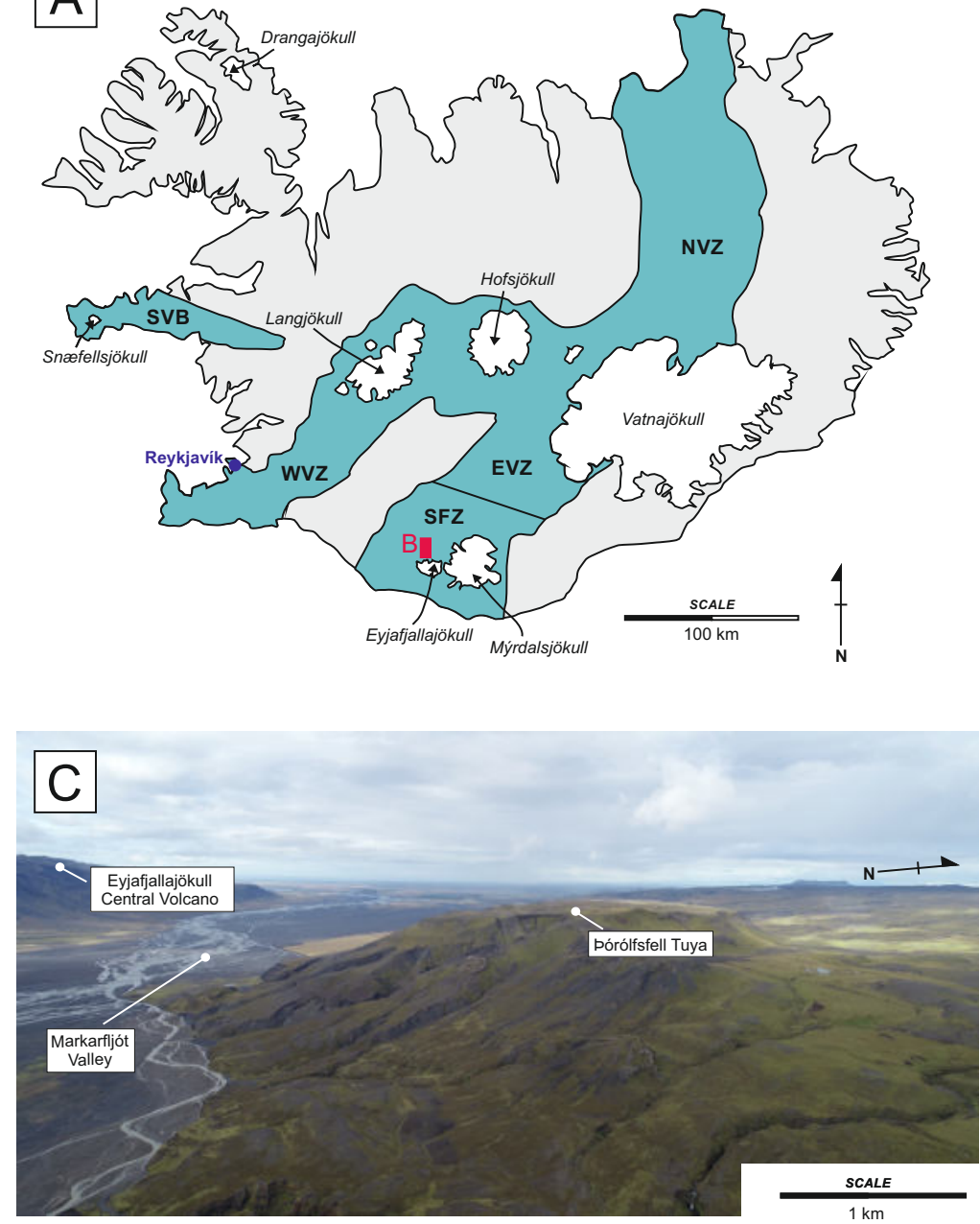

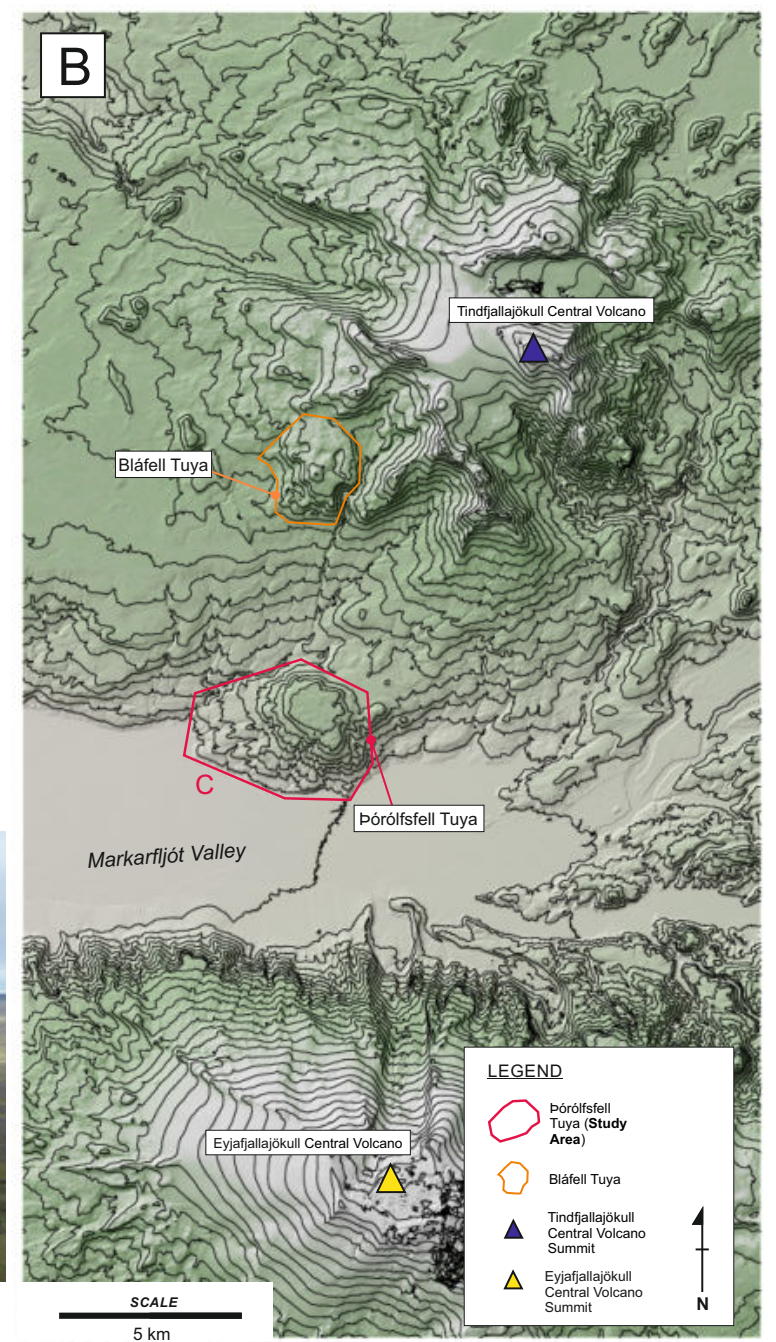




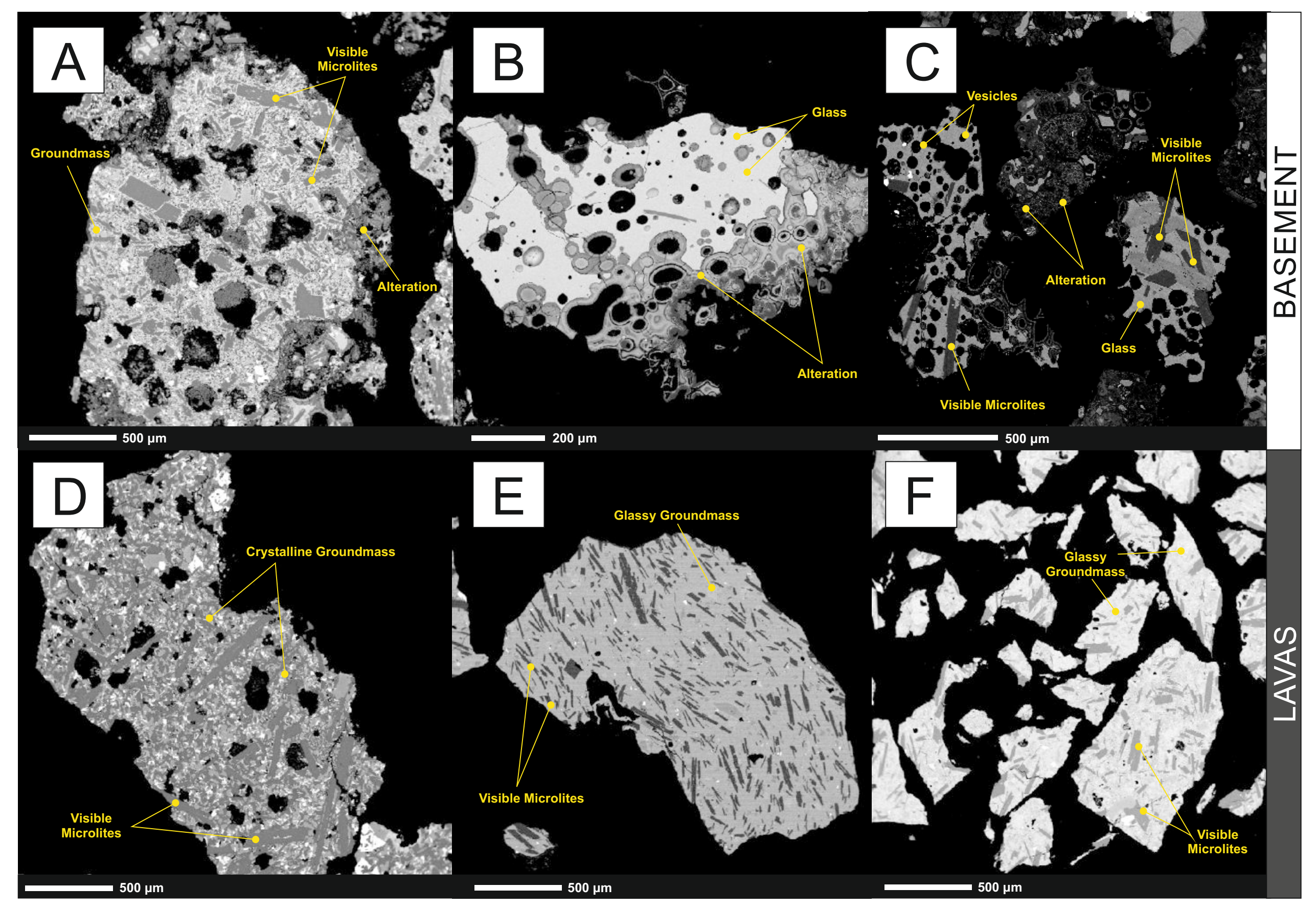



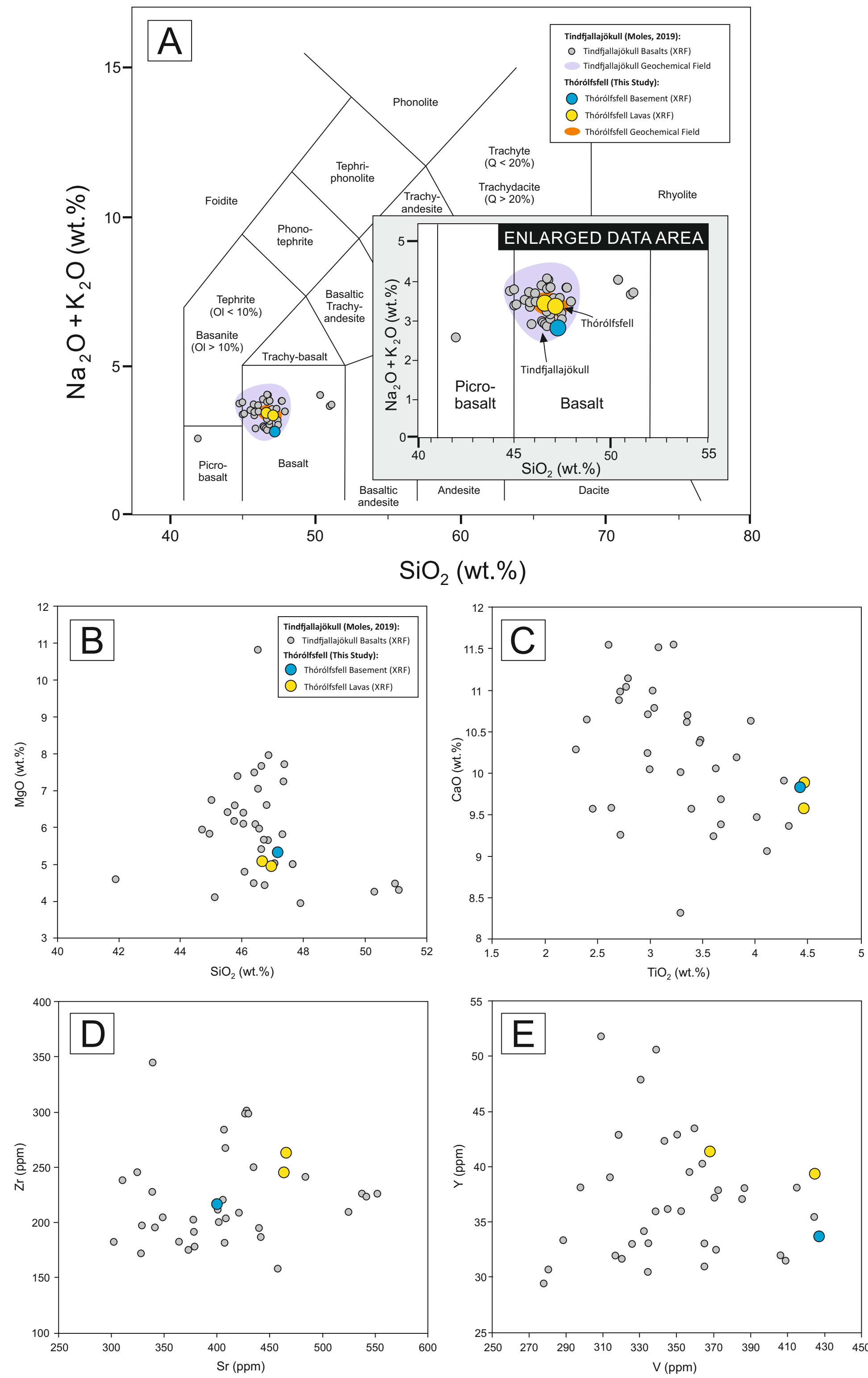


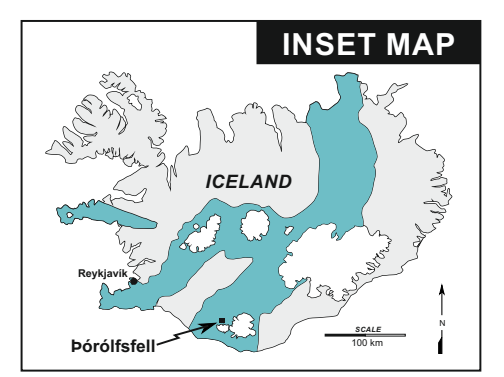

A GENERALZZD VERTICAL
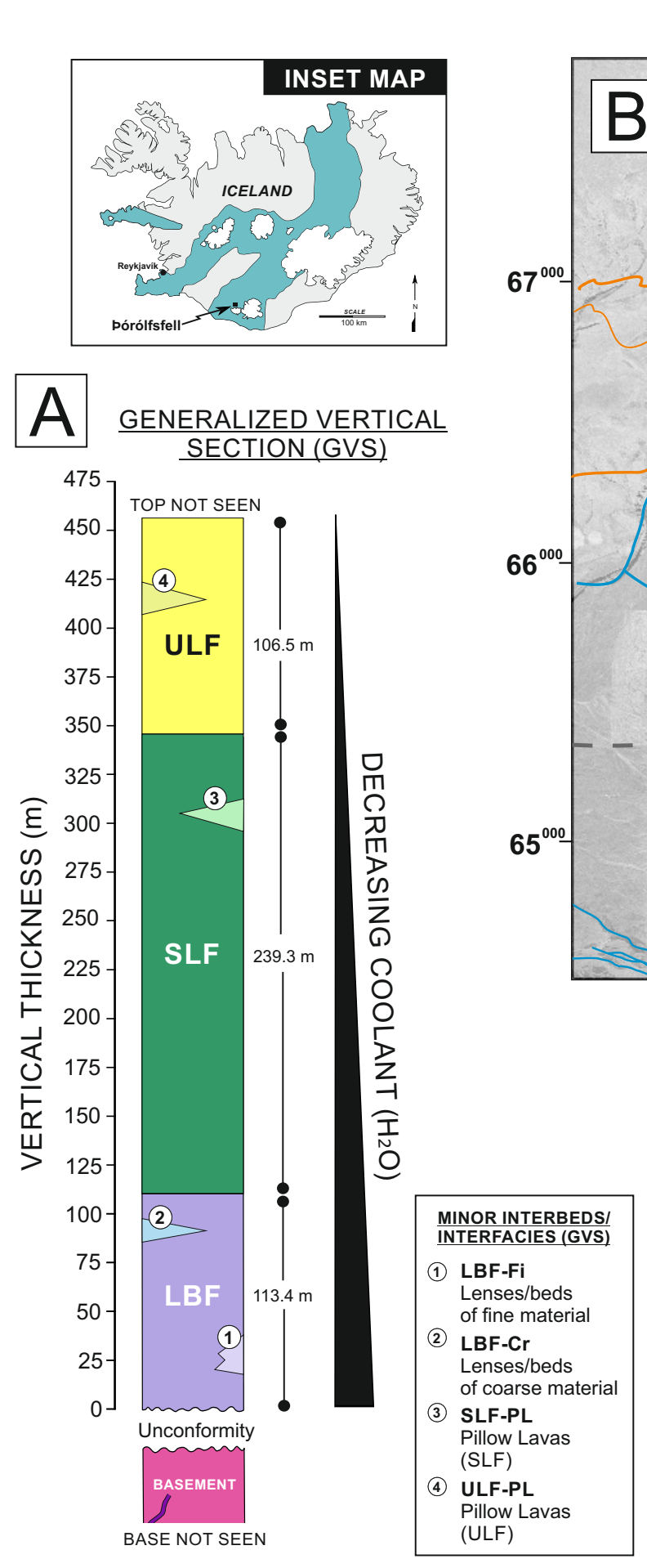

$65^{000}$

$67^{000}$

$68^{000}$

PÓRÓLFSFELL TUYA

LITHOFACIES DISTRIBUTION

(Solid Volcanic Geology)

$\frac{\text { SCALE }}{1 \mathrm{~km}}$

LEGEND

- - Contact _ River

12. Dip and Strike

Tuya boundary

${ }^{44 \mathrm{~m}}$ - Spot height

Road

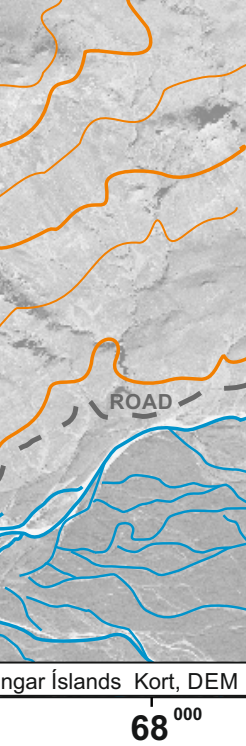

C schematic sub-surface geology along line of Section A-A'

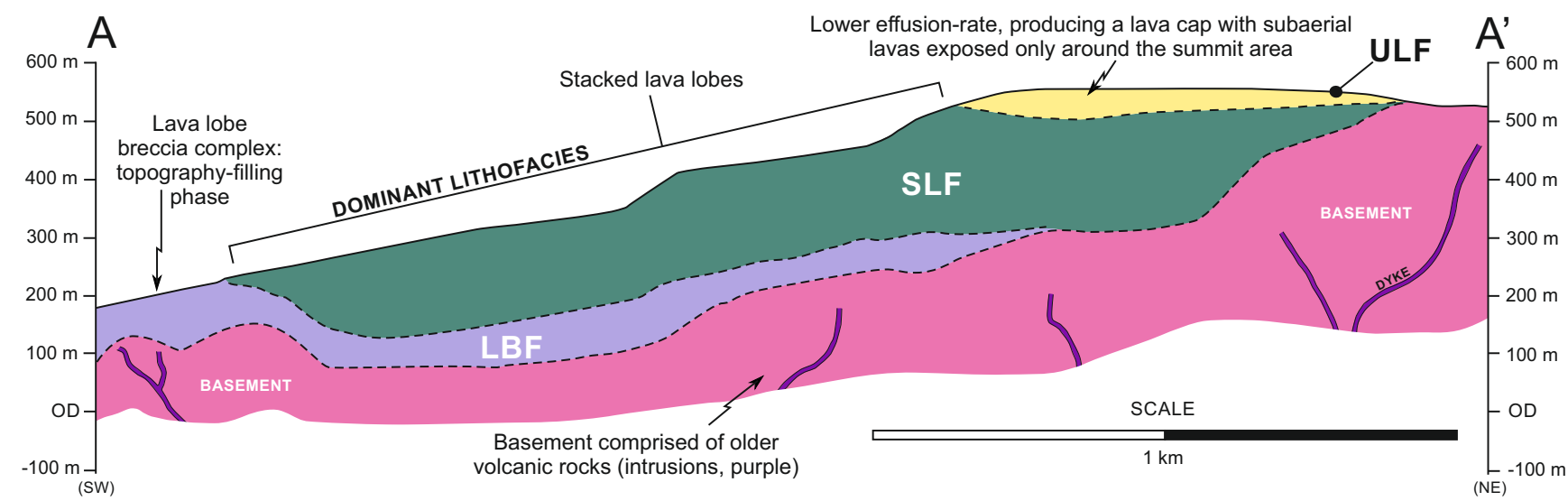




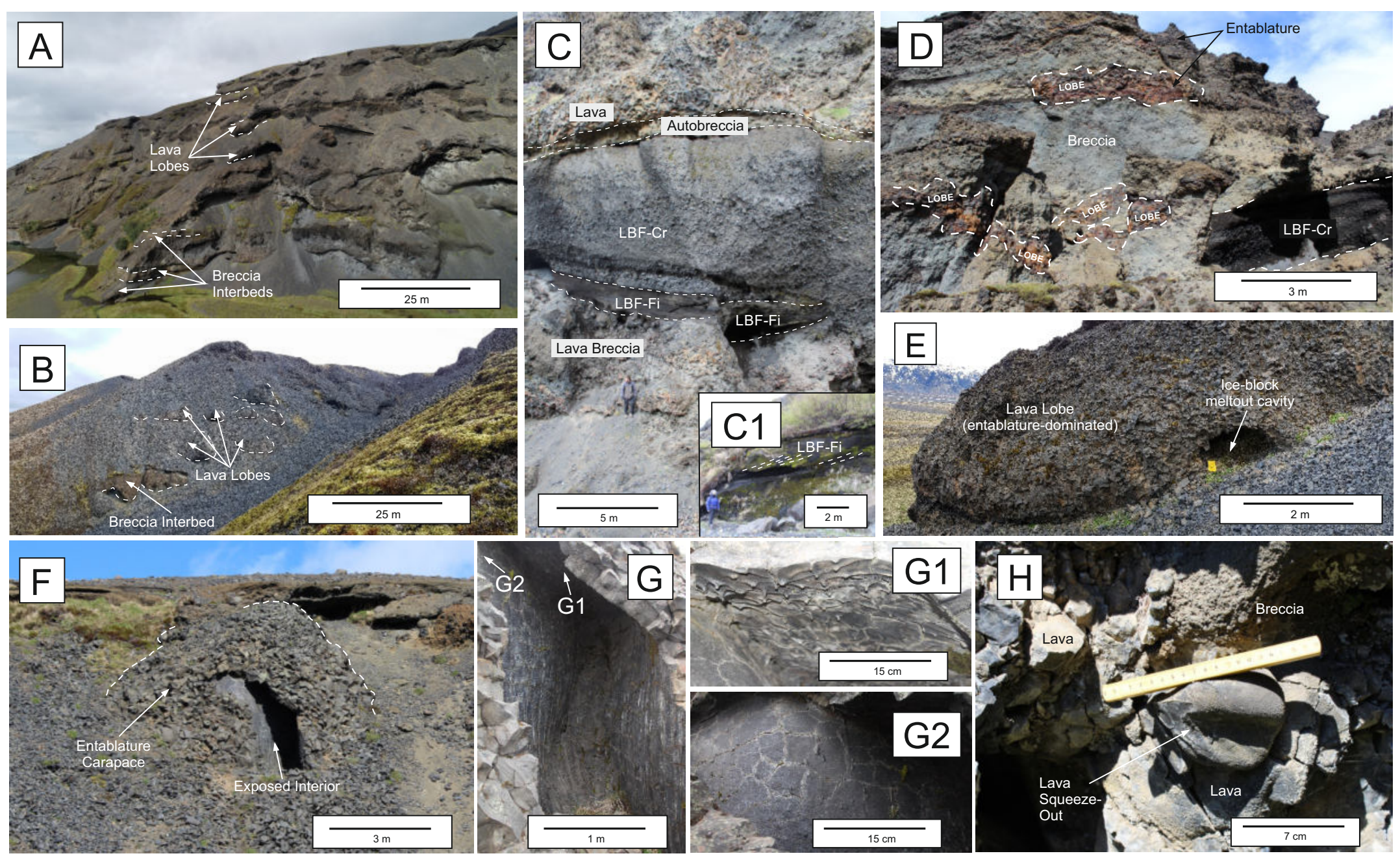



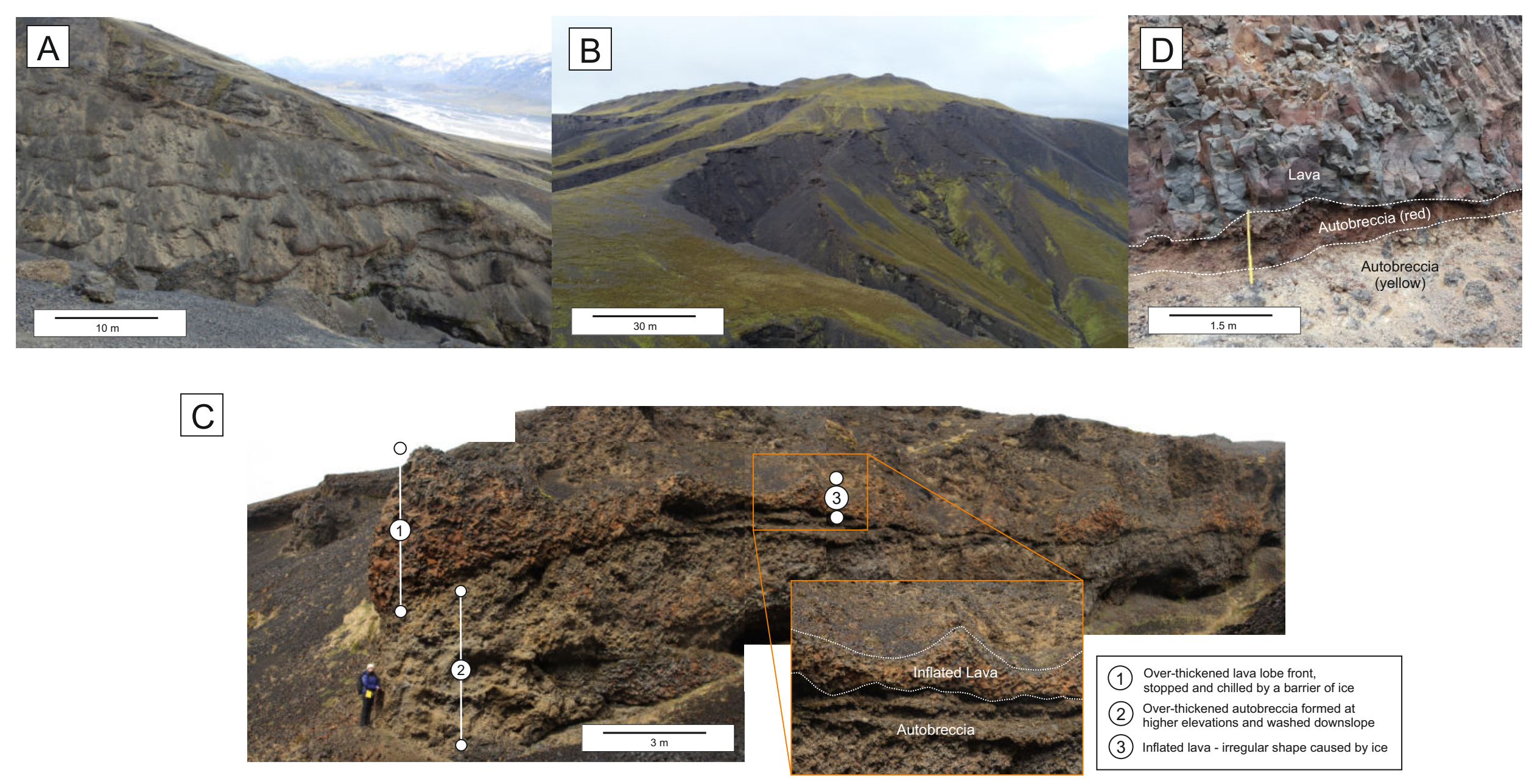

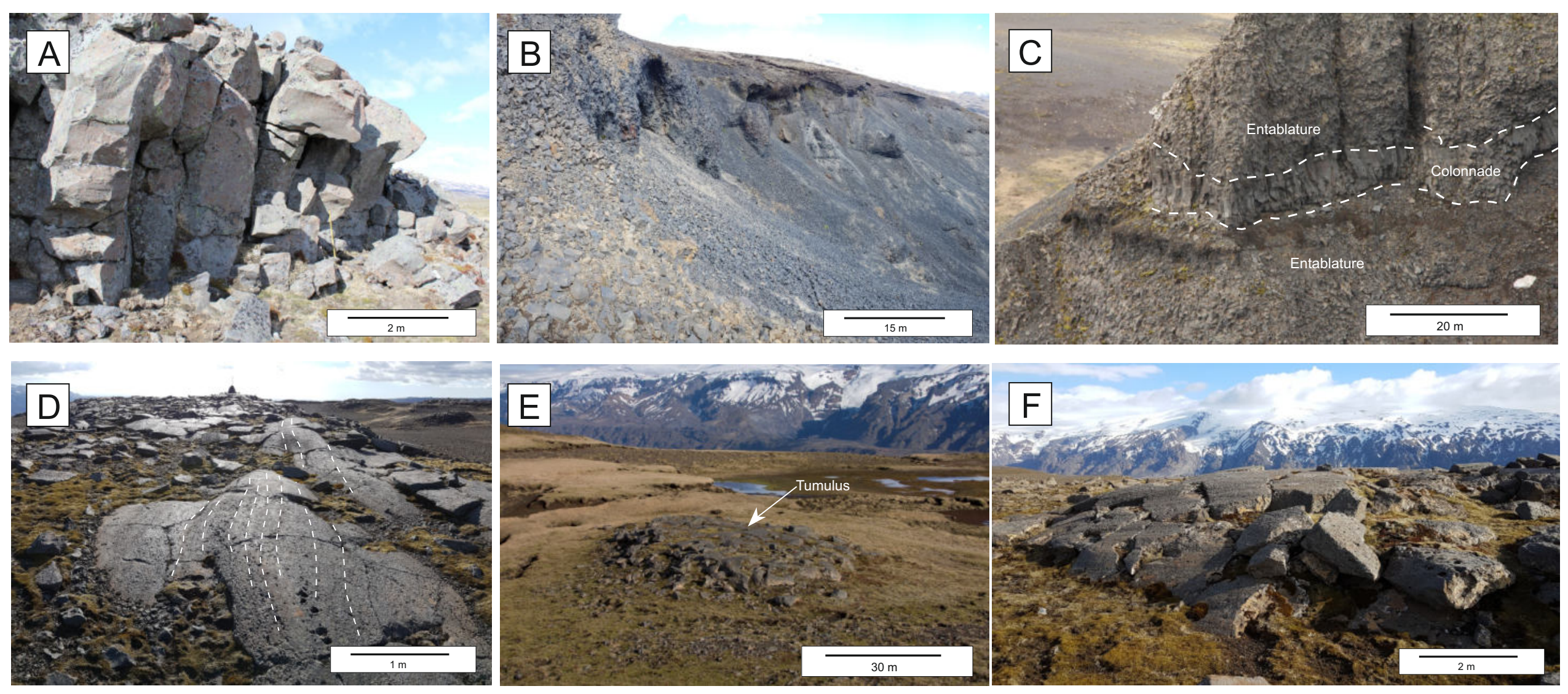

G
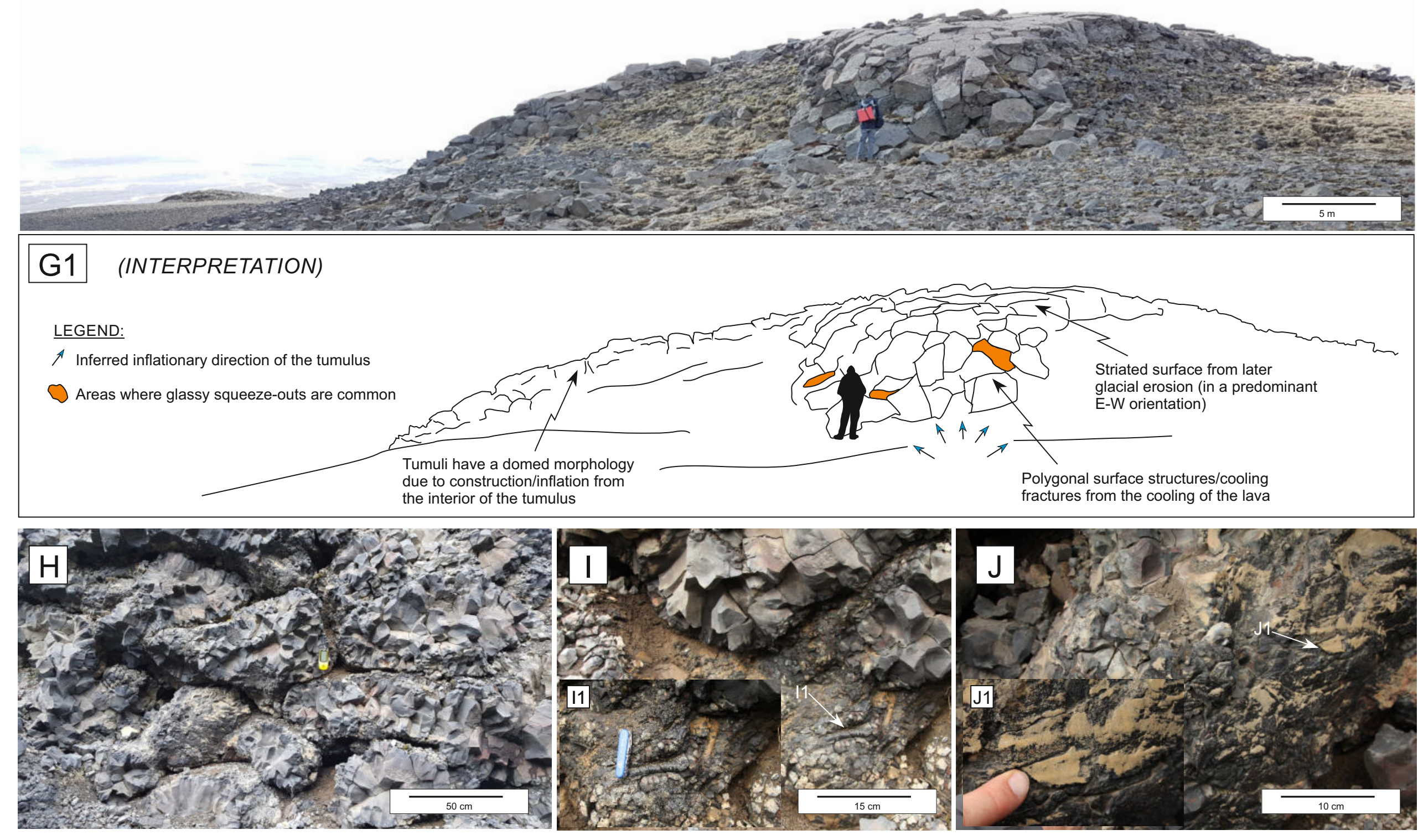

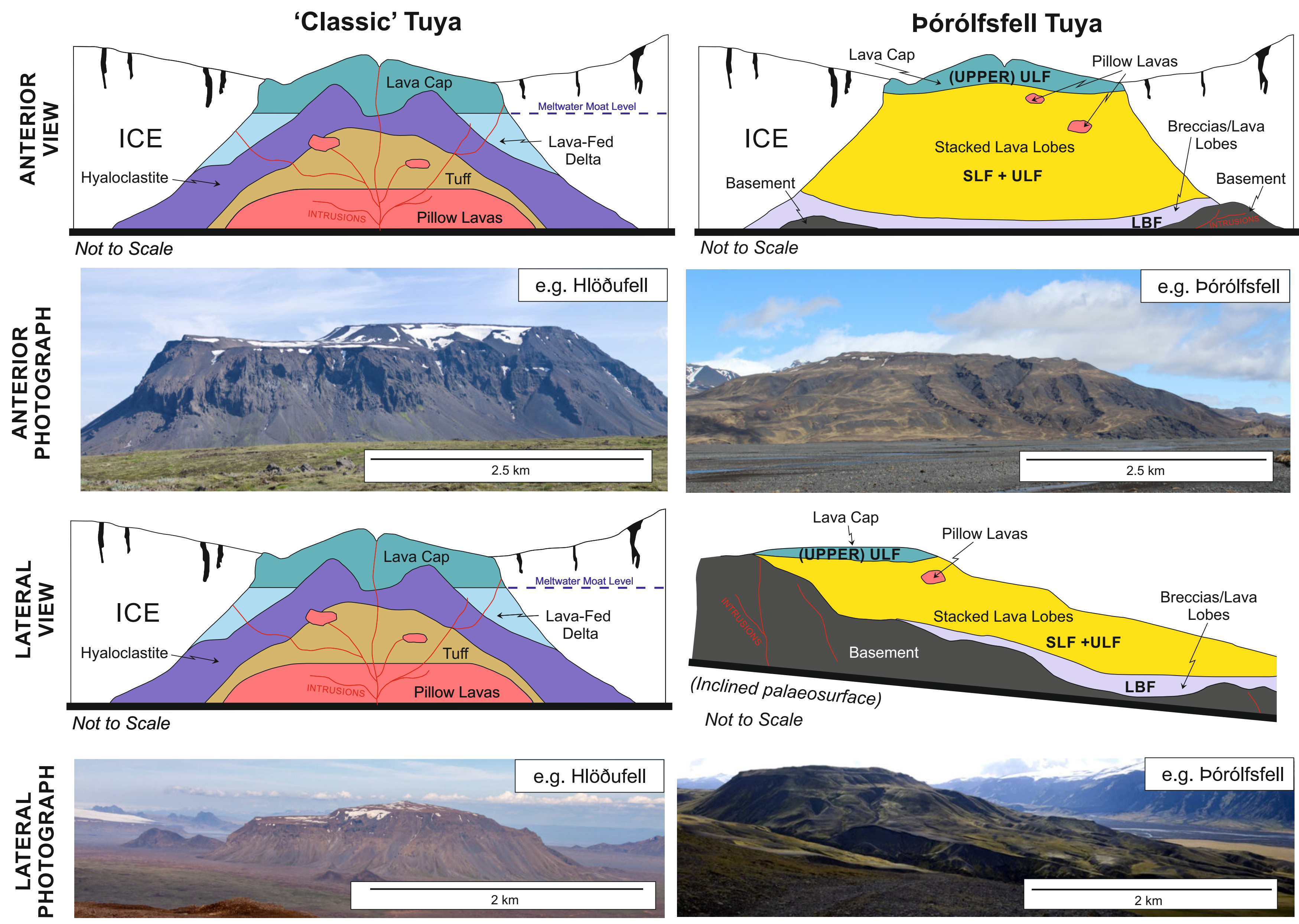


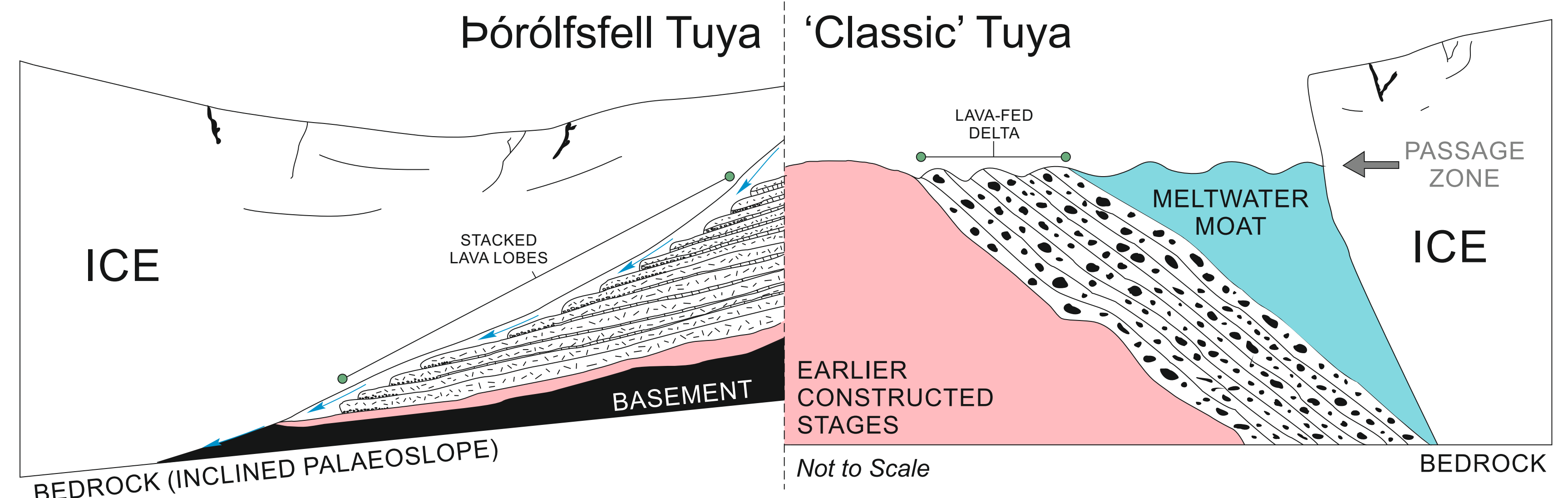

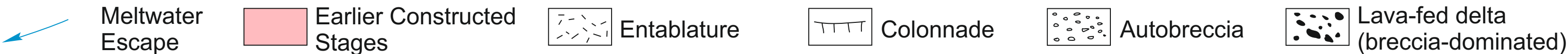



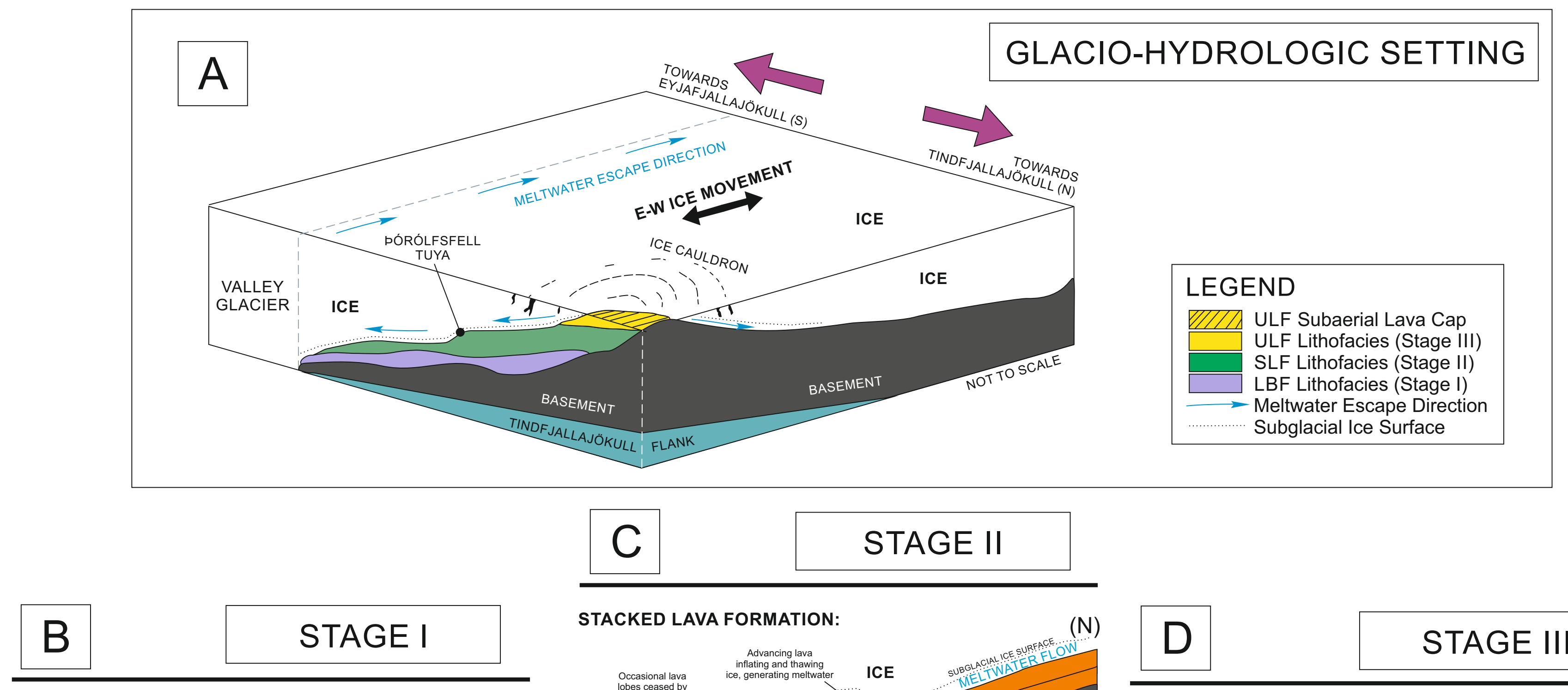

STACKED LAVA FORMATION:

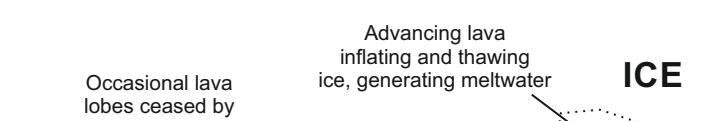

(S)

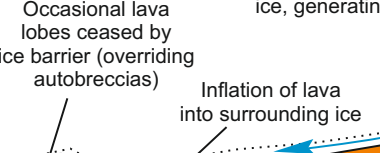
ICE
BARRIER:

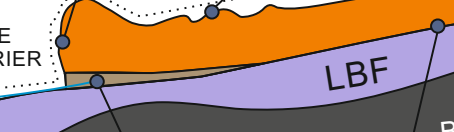

(N)

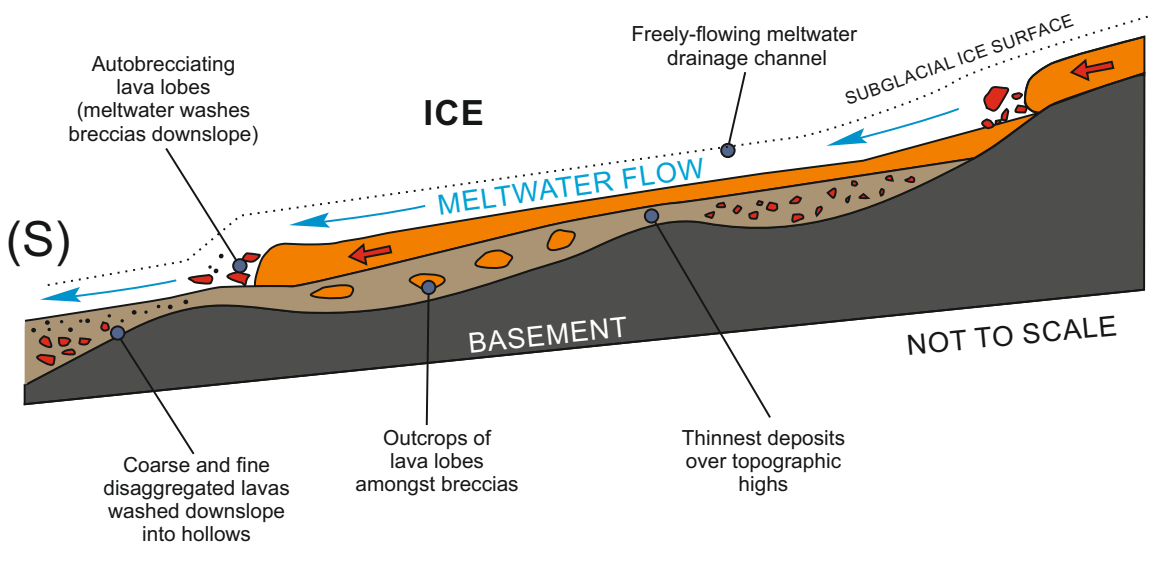

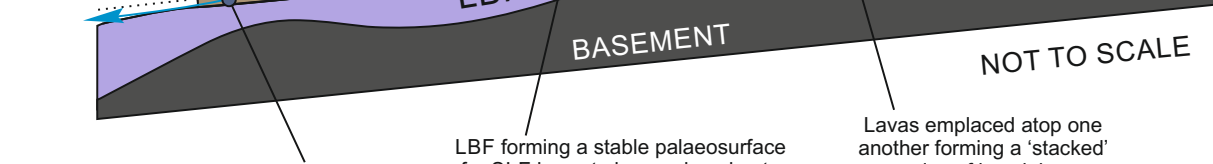

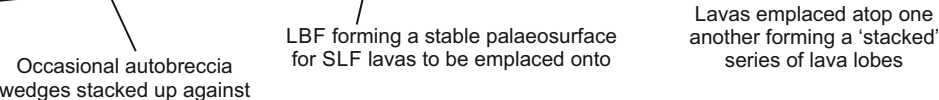
wedges stacked up agains
ice barriers (tapered to $\mathrm{N}$ )

MINOR PILLOW LAVA FORMATION:

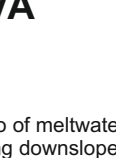

(S)

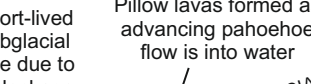

ICE ablockage ICE ro 00.08080909
(N)
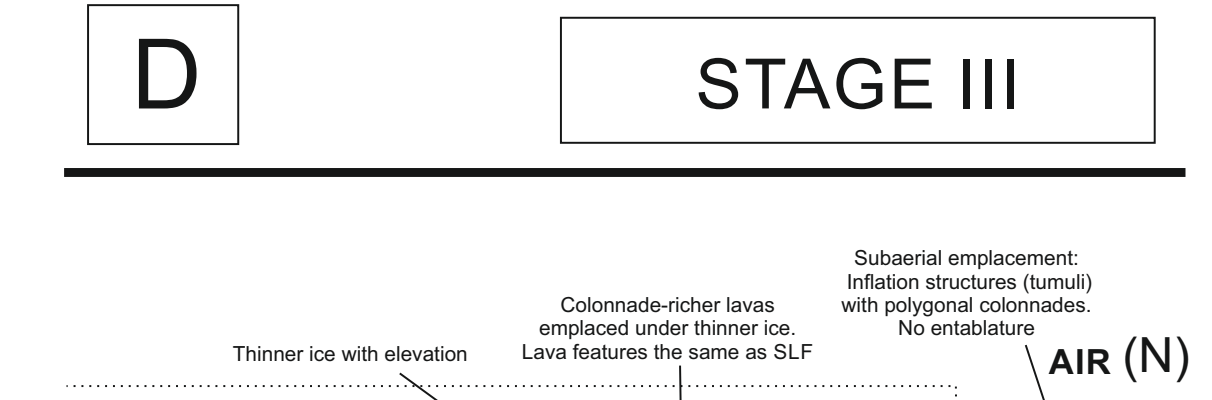

(N)

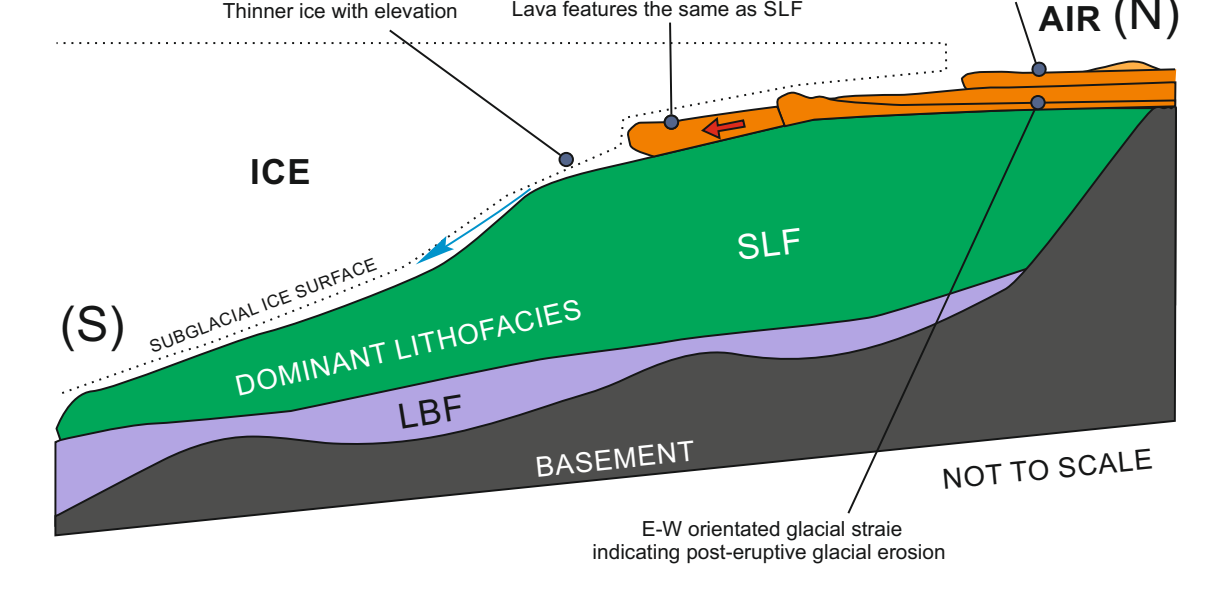




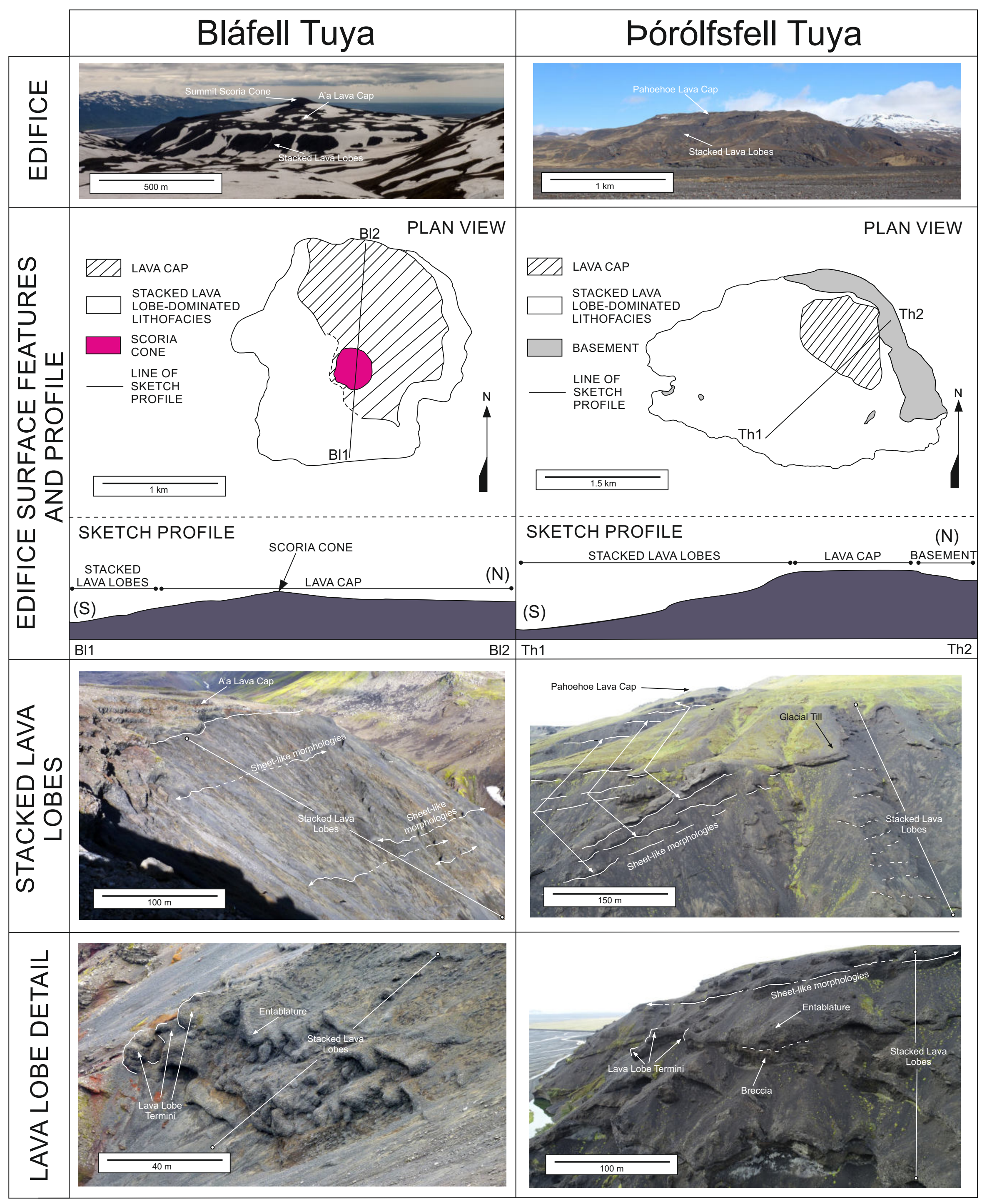


Table 1. Whole-rock (XRF) major and trace element compositions from Thórólfsfell, South Iceland. To account for a variety in hydration and for comparative purposes, major element concentrations are normalised to a $100 \%$ volatile free basis.

\begin{tabular}{|c|c|c|c|c|c|c|c|c|c|c|c|c|c|}
\hline \multicolumn{14}{|c|}{ XRF (Whole-rock analyses) } \\
\hline & Major Elem & (wt. \%) & & & & & & & & & & & \\
\hline Associated Lithofacies & Sample ID & $\mathrm{SiO}_{2}$ & $\mathrm{TiO}_{2}$ & $\mathrm{Al}_{2} \mathrm{O}_{3}$ & $\mathrm{Fe}_{2} \mathrm{O}_{3(t)}$ & $\mathrm{MnO}$ & $\mathrm{MgO}$ & $\mathrm{CaO}$ & $\mathrm{Na}_{2} \mathrm{O}$ & $\mathrm{K}_{2} \mathrm{O}$ & $\mathrm{P}_{2} \mathrm{O}_{5}$ & LOI & Total [Analytical total] \\
\hline Thórólfsfell Basement & AH-1A & 47.16 & 4.42 & 12.87 & 16.85 & 0.23 & 5.32 & 9.84 & 2.24 & 0.58 & 0.50 & 6.355 & 100 [92.61] \\
\hline Thórólfsfell Lava (SLF) & $\mathrm{AH}-2 \mathrm{~A}$ & 46.66 & 4.46 & 12.73 & 16.94 & 0.23 & 5.09 & 9.88 & 2.77 & 0.69 & 0.54 & -1.03 & 100 [99.97] \\
\hline \multirow{2}{*}{ Thórólfsfell Lava (ULF) } & $A H-3 B$ & 46.97 & 4.45 & 13.05 & 16.80 & 0.24 & 4.96 & 9.58 & 2.71 & 0.68 & 0.57 & -0.32 & 100 [99.41] \\
\hline & Trace Elem & ppm) & & & & & & & & & & & \\
\hline Associated Lithofacies & Sample ID & $\mathrm{Zn}$ & $\mathrm{Cu}$ & $\mathrm{Ni}$ & $\mathrm{Cr}$ & $\mathbf{v}$ & Sc & Ba & $\mathrm{Nb}$ & $\mathrm{Zr}$ & $\mathrm{Y}$ & Sr & $\mathbf{R b}$ \\
\hline Thórólfsfell Basement & AH-1A & 155 & 78 & 32 & 0 & 427 & 33 & 158 & 32 & 216 & 34 & 400 & 13 \\
\hline Thórólfsfell Lava (SLF) & $\mathrm{AH}-2 \mathrm{~A}$ & 143 & 61 & 23 & 1 & 425 & 31 & 177 & 37 & 245 & 39 & 464 & 14 \\
\hline Thórólfsfell Lava (ULF) & $A H-3 B$ & 155 & 38 & 17 & b.d* & 368 & 29 & 172 & 41 & 263 & 41 & 465 & 14 \\
\hline
\end{tabular}


Table 2. Table of lithofacies codes, calculated unit thicknesses, descriptions, eruption stages and generalised emplacement mechanism for the effusive lithofacies at the Thórólfsfell basaltic tuya, south Iceland.
\begin{tabular}{lcc}
\hline Lithofacies [Eruptive Stage] Code & Unit Thickness $(m)^{*}$
\end{tabular}

Uppertava Formation

ULF-PL

$\sim 110$ (min.)

[Stage III]

Stacked Lava Formation

[Stage II]

Lava Breccia Formation

LBF,

[Stage I]

LBF-Fi,

113.4

BF-Cr
Description

Lava lobes are stacked and display similar features to SLF with a decrease in entablature with stratigraphic height. The contact between SLF and ULF is marked by a 40:60 colonnade to entablature ratio. The uppermost surfaces of ULF (upper c.20 m) display pahoehoe lavas with tumuli, exhibiting polygonal jointing and well-formed striae in their colonnades. Pipe vesicles (up to $2 \mathrm{~cm}$ ) are common, particularly towards the base of the colonnades. Squeeze-outs occasionally occur within polygonal joints. Lava groundmass is vesiculated with rounded vesicles up to $12 \mathrm{~mm}$ in diameter. Minor outcrops of pillow lavas (ULF-PL) exhibit prismatic exposures of ULF are glacially striated in a general E-W orientation, parallel to the Markarfljót valley.

Stacked lava lobes up to $11 \mathrm{~m}$ thick, extending laterally for over tens to hundreds of metres. Some lava lobes demonstrate glassy, inflated flow-fronts, typically 2-5 $\mathrm{m}$ thicker than the average lava thickness of a given flow. Lavas are largely dominated by

entablature jointing, with lower basal colonnades, which increase in size with elevation. Autobreccias occasionally occur, near to flow-fronts, comprising spalled lava fragments and clasts of the overlying lava amongst a fragmental matrix. Where autobreccias occur, they are thickest beneath lobe fronts, and are up to $3 \mathrm{~m}$ thick. Baking intensity of this autobreccia decreases with distance
from the flow base, marked by a colour gradation from red to brown.

列 by sharp aspentes a ditionally, small elongated are occasionally exposed. Pillows are rounded and display glassy rinds with prismatic jointing radiating from the core to rind. A thin

matrix, comprised of spalled glass, fills interstitial spaces between pillows.

Lava lobes and associated breccia comprising lenses and minor interbeds/interfacies of fine lava fragments (LBF-Fi) and coarser beds (LBF-Cr). LBF-Fi is composed of devitrified, dark brown glassy lava fragments with scattered blocks up to $12 \mathrm{~mm}$ in size Sag textures occur around some of these blocks. LBF-Fi is often cross-stratified with lee slopes preserving a southerly transport direction. LBF-Cr comprise clast-supported blocks of grey lava with individual clasts up to $14 \mathrm{~cm}$ in diameter. Lava lobes within LBF typically have a high fracture density of c. $280 \%$ entablature jointing. Colonnades are only present at the base and within flows. No striae occur

within the colonnades and individual columns are no wider than $12 \mathrm{~cm}$. Lava lobe sizes increase with elevation. Many lobes exhibit pseudopillow fracturing throughout. Bedding is variable within this unit ranging from $12-52^{\circ}$. Lava 'tongues' cascade over

topography in regions of oversteepened topography and lava balls are also present. The inside of the lobes are smooth, with smal ridges, grooves and drip structures, composed of glassy to microcrystalline lava. These vary in size and shape from c.3 $\mathrm{m}$ rounded
Emplacement Environment

cial to subaerial: Stacked lava lobes as

sheets at the ice-edifice interface. Some

minor, temporary periods of standing water.

Uppermost lavas emplaced subaerially.

Subglacial: Stacked lava lobes as sheets at the ice-edifice interface. Some minor, temporary periods of standing water.

Subglacial: Lava lobe emplacement into an irregular basement topography.

* Unit thicknesses for ULF, SLF and LBF have been calculated by converting the distances on the gesological map in fig. 4 ( (along the average dip direction to the S/SW) to meters. An average dip angle of $12^{\circ}$ was used. Multiply
provided the units with true thicknesses of the lithofacies. This has been tested by adding the thicknesses of ULF, SLF and LBF, which equal the height of Thórollsfell, when further adding the basal elevation above OD level. 
Table 3. Comparison between the eruptive, glacio-hydrologic and dynamic processes at Thórólfsfell (This Study) and The Table (Wilson et al., 2019).

\begin{tabular}{|c|c|c|}
\hline Tuya Characteristic & Thórólfsfell (This Study) & The Table (Wilson et al., 2019) \\
\hline Composition & Basalt & Andesite \\
\hline Eruption Style & Effusive & Effusive \\
\hline Eruption Rate & Waning & Steady \\
\hline Ice Confinement & Throughout eruption & Throughout eruption \\
\hline Edifice Cross-Sectional Symmetry & Asymmetrical & Symmetrical \\
\hline Lithofacies & $\begin{array}{l}\text { Stacked lava lobes and associated breccias (LBF), Stacked lava lobes with occasional } \\
\text { autobreccias and very minor localised pillow lavas (SLF and ULF), pahoehoe cap lavas } \\
\text { (uppermost surface of ULF) }\end{array}$ & Quench breccias, intrusions (emplaced as lava into ice) \\
\hline Emplacement Mechanism & Lava flows downslope from high to lower elevations & Dyke injection and endogenous inflation, near vertically \\
\hline Growth & $\begin{array}{l}\text { Exogenous growth (stacked lava lobes). Strong evidence for progressive upwards } \\
\text { growth and successive lava layering }\end{array}$ & $\begin{array}{l}\text { Endogenous (inflation within ice). No evidence for upwards growth or } \\
\text { successive lava layering }\end{array}$ \\
\hline Orientation of Lavas & Dipping downslope (c. $12^{\circ}$ ) & Near vertical \\
\hline Morphology of Lavas & Lobes in sheet-like orientations & Intrusive bodies \\
\hline Lava Breccias & $\begin{array}{l}\text { Formed during initial phase of eruption, and collecting in depocenters on the } \\
\text { irregular basement }\end{array}$ & Quench breccia from initial contact with ice \\
\hline Meltwater Production & Diminishing throughout the growth of the tuya & Constant (low) \\
\hline Meltwater pathway formation & $\begin{array}{l}\text { Pre-existing subglacial pathways further exploited by pulses of meltwater generated } \\
\text { by advancing lobes }\end{array}$ & $\begin{array}{l}\text { Largely formed by quench breccia. Some pre-existing subglacial pathways } \\
\text { exploited by escaping meltwater }\end{array}$ \\
\hline Subaqueous evidence & $\begin{array}{l}\text { Minor examples only (i.e. small isolated bodies of pillow lavas where water had been } \\
\text { trapped in local depocenters). Evidence for water-cooled lobes due to effective } \\
\text { drainage of meltwater and 'drying-up' sequence due to gradually diminishing } \\
\text { meltwater availability with elevation }\end{array}$ & $\begin{array}{l}\text { No evidence for subaqueous eruption (i.e. no pillow lavas, no pillow } \\
\text { breccia, and no hyaloclastite) }\end{array}$ \\
\hline $\begin{array}{l}\text { Evidence for meltwater influence } \\
\text { on lithofacies }\end{array}$ & $\begin{array}{l}\text { Strong. Water-chilled upper surfaces of all Stage I and II lavas. Collections of breccia } \\
\text { in depocenters sometimes related to downward migration of fragmented material } \\
\text { by water (e.g. LBF-Fi) }\end{array}$ & None \\
\hline $\begin{array}{l}\text { Evidence for bedrock influence on } \\
\text { lithofacies }\end{array}$ & $\begin{array}{l}\text { Spatial distribution of lithofacies and emplacement conditions determined by } \mathrm{c} .12^{\circ} \\
\text { sloping bedrock }\end{array}$ & None \\
\hline Rate of meltwater drainage & Medium to High (inferred) & High (inferred) \\
\hline Heat transfer between lava and ice & Low (inferred) & Low (modelled) \\
\hline Intrusions & Absent & Abundant throughout tuya/comprises tuya \\
\hline $\begin{array}{l}\text { Substantial Meltwater } \\
\text { Accumulation }\end{array}$ & Absent & Absent \\
\hline Post-eruptive glacial overriding & Minor smoothing of uppermost surfaces (ULF) from post-eruptive glacial movements & None \\
\hline
\end{tabular}

